\title{
A KEY TO THE PLANTS OF THE SUBALPINE AND ALPINE ZONES OF THE KOSCIUSKO REGION
}

\author{
JoY THOMPSON
}

(Accepted for publication 13.2.1981)

\begin{abstract}
Thompson, Joy (National Herbarium of New South Wales, Royal Botanic Gardens, Sydney, Australia. 2000) 1981. A key to the plants of the subalpine and alpine zones of the Kosciusko region. Telopea 2(3): 219-297 - The paper consists of a key to the vascular plants of the Kosciusko region of southern New South Wales (S. of $36^{\circ} \mathrm{S}$.) and brief notes on habitat within, and distribution within and outside the region. The introduction delimits the subalpine and alpine zones, gives an account of their recent history and discusses the origin and distribution of the region's flora. An index to families appears on p. 297. (Plant Systematics: Plant Distribution).
\end{abstract}

\section{INTRODUCTION}

The material forming the basis of this key was assembled by me as a result of several field trips made in the Snowy Mountains area in the early 1950's. These trips, which involved study in the area from the Mt Kosciusko summit to the headwaters of the Happy Jacks River, were made in the company of Dr Joyce W. Vickery of the National Herbarium of New South Wales and Dr Marie E. Phillips who was then attached to the Snowy Mountains Authority. The energies of both my colleagues were at that time directed principally toward the grass genus Poa, and resulted in Dr Vickery's revision of this difficult genus (Vickery, 1970), and in her recognition of a pattern of species-diversity based on ecological requirements which has proved of tremendous importance for a general understanding of the flora of the region. It was my good fortune, therefore, to be introduced to the district by two distinguished botanists with an awareness of the complexity and significance of the flora. My interest in the region was kindled then and has continued and intensified over the years. Each summer for the last 13 years I have been able to spend one or two weeks in the area, and although this has barely given me time to assess in a rudimentary way the complex problems that exist, it is hoped that the following key and associated notes will form the basis for future biological study in this region. In matters of disagreement with recent publications on plant groups involved I have annotated my key. Many of my decisions have been made as a result of consultation with my colleagues at the National Herbarium of New South Wales and with Mr Max Gray of the Herbarium Australiense, Canberra, whose extremely wide knowledge of the flora of the alpine area of Kosciusko has been made available to me. The responsibility for all names used and opinions expressed in the key is, for better or worse, mine. 


\section{ALPINE AND SUBALPINE ZONES}

Mt Kosciusko is the highest point on the Australian continent and is located at the southern end of the tablelands of eastern New South Wales. It is here that a tilted plateau has its highest part and presents a number of peaks ascending above the treeline. This plateau area has been divided by Costin (1954) into four floristic zones of which each of the upper two, the alpine and subalpine, supports a flora including a number of species not found elsewhere in mainland Australia. It is to these two altitudinal zones that I have confined my work.

Throughout this work a reference to the alpine zone denotes the area which extends above the upper limit of tree growth, the tree-line. The tree species at this upper limit is the "Snow Gum", Eucalyptus pauciflora ssp. niphophila. It fails to establish itself at heights above $1830 \mathrm{~m}$ (approx.) on much of the Kosciusko plateau but reaches a height of $1900 \mathrm{~m}$, or even $2000 \mathrm{~m}$, on steep rocky mountainsides such as those of the Ramshead Range, above Thredbo Village, and the Perisher Range. The alpine zone is extremely limited in extent but includes not only the peaks surrounding Mt Kosciusko and the intervening valleys but other outlying peaks such as Gungartan, $2068 \mathrm{~m}$, and Jagungal, $2061 \mathrm{~m}$ (see map, Thompson \& Gray, inside back cover). On the peaks north of $\mathrm{Mt}$ Anderson the alpine zone has not been studied as thoroughly as that of the main range to the south but my observations indicate that the zone there lacks a number of species found on the southern peaks. This may be due to the greater vulnerability which these more gently sloping mountains offered to the effects of stockgrazing, with the consequent erosion of their late-snow areas. It may be due also to their more northerly position, but the most likely explanation is that the less complicated terrain of these mountains provides fewer ecological niches. The word "alpine" is often used in other disciplines, and by Australians generally, for that part of the whole Kosciusko area where snow falls and may lie for extended periods (which would include the upper part of the montane zone), and the use of this term in most non-botanical contexts should therefore be accepted with reservation. In many botanical works the term is used, especially in vernacular names, for species which do not extend above the tree-line.

For the purposes of this work it has been more difficult to identify clearly that larger area $I$ define as the subalpine zone. This is, for the most part, distinguished by the presence of E. pauciflora ssp. niphophila, although this species is absent from the cold-air-drainage valleys lying between the tree-covered hillsides. The subalpine zone, generally speaking, lies within the altitudes of $1500 \mathrm{~m}$ and $1900 \mathrm{~m}$. The lower limit is lower still on the cold-air plain found in the Happy Jacks River catchment; its delimitation is at present somewhat arbitrary as near the lower limit the subalpine zone will allow the invasion of montane species, especially in sheltered valleys.

This present study therefore includes all that area of land in New South Wales over $1500 \mathrm{~m}$ alt. south of $36^{\circ} \mathrm{S}$. latitude, with the enclosed cold-air valleys and some areas of slightly lower altitude but similar floristic composition. Beyond the area under review the subalpine zone continues northward, and floristically similar, though not identical, areas extend into the Australian Capital Territory (geographically wholly included in the Southern Tablelands of New South Wales). Beyond this, subalpine vegetation in New South Wales is restricted to small pockets at Barrington Tops $\left(32^{\circ} \mathrm{S}\right.$. lat.) and near Ebor $\left(30^{\circ} 25^{\prime} \mathrm{S}\right.$. lat.), the latter representing the northern limit of such vegetation in Australia. These northern areas are poor in obligate high-altitude species but a floristic comparison could provide an interesting study. Unfortunately the composition of the flora in Australia's limited subalpine areas has been altered by grazing, for stock penetrated these areas long before botanical exploration, so that reconstruction of floristic relationships may now be impossible. For example, Gingidia harveyana, represented in herbaria by specimens from Ebor Falls, colleeted in 1941, has not been found there since, and may now be extinct on the Northern Tablelands. 


\section{RECENT HISTORY AND THE EFFECTS OF WHITE SETTLEMENT}

Botanical exploration of the Kosciusko area can be said to have begun with the visit to the region, in the summer of 1854-55, of F. Mueller, on one of the exploratory and collecting trips he undertook after his appointment as Victorian Government Botanist. In spite of the interest Mueller's collections aroused in the botanical world, Australians were slow to appreciate the scientific value of the high-altitude flora, appreciating instead the rather limited value of the summer grazing it provided, a value which graziers soon attempted to enhance each year by setting fire to whatever would burn as they withdrew their stock before the first snow. By the time of Mueller's visit to the Kosciusko summit area, pastoralists were well-established in the surrounding districts and stock may well have already found their way to the high country. Soon summer grazing was so well-established that before the century was out both R. Helms (1893), who collected for the Australian Museum, and J. H. Maiden (1898), then the New South Wales Government Botanist, drew attention to the damage this grazing was causing. However stock were not effectively removed from the region until 1958 , and, in fact, can still be seen occasionally in the northern section.

The effects of grazing are long-lasting and have touched many of the significant areas of botanical enquiry at Kosciusko, bringing an element of uncertainty to assumptions concerned with the original state of the flora. It is not fanciful to suggest that the tree-line may now be lower than it was before grazing and the associated burning altered the area. Old photographs show trees on the sides of valleys that are now treeless. Though occasional stunted trees can be found in rock-clefts in alpine valleys, the removal of trees from these hillsides has apparently altered the local climate to one that is too rigorous to allow the re-development of woody growth, or at least to one that provides opportunity for a dense, mainly herbaceous, cover giving little room for penetration by a less-favoured species, a condition observed in subalpine transects by Wimbush \& Costin (1979). It would appear that this alteration in the treeline is an irreversible change, though herbaceous plants may be capable of reestablishing themselves. The grass, Chionochloa frigida, conspicuous in photographs taken at the turn of the century, was rarely seen in the 1940's but is now abundant and still spreading rapidly. This resurgence has been a surprise to those who have observed the area over the period.

There is a well-recognised group of feldmark plants found on a band of phyllite outcropping along the high ridge of the main range. These species have evolved in, or migrated to and survived in, this stressful environment of broken rock and strong wind. As late as 1956, 12 years after grazing was prohibited in the alpine area (in order to minimise the obvious erosion occurring rather than to preserve the unique flora), I watched a small flock of sheep running across the feldmark above Club Lake. As both cattle and sheep were frequently seen in this very high country in the 1950s, I have since wondered whether it is significant to the survival of this feldmark flora that this area has a softer and more resilient soil-type composed of almost vertically bedded phyllite breaking down to fine soil held between the upright ridges and beneath the scattered broken rock particles. Plants collected in the area are well-rooted, with fine soil adhering to their roots. The general aspect of this feldmark does not appear to have changed significantly in the years 1 have been observing it. It is possible that many of the plants now restricted or almost restricted to these phyllite areas, or other restricted species, may once have inhabited and been eliminated by stock from the high-wind and broken-rock areas on the more extensive gneissic granite of the rest of the alpine region. These exposed granite areas now have a very limited flora and it is obvious that any new arrival would have difficulty establishing itself among the coarse granite particles left there by the wind. 
Perhaps the most floristically significant parts of the alpine zone are the snowpatch communities in the lee of each mountain-top. It is here that many of the obligate alpines and some of the most restricted species grow, and it is here that the sheep camps over the years have done the most damage. If recovery of all these areas is possible, it will not be for a very long time. Many of these late-snow places have shown little recovery in the nominally 35 years, but perhaps actually 25 years, since grazing has been withdrawn from them.

It is still too soon to assess the long-term effect of grazing and burning on the specialized flora of Kosciusko. Cyclical changes do occur, but it is obvious that more than 100 years of misuse has irrevocably altered the distribution of much of the region's flora.

\section{THE FLORA AND ITS RELATIONSHIPS}

Many of the plant groups treated in the present work are under review by other workers. In order not to use unpublished names, many of the taxa must appear as $\mathrm{sp}$. or ssp. Most of these can later be related to revisions by their distribution or other information given with the key. However, many of the taxa are not the subjects of forthcoming revisions but have been found by me, and often independently by $\mathrm{Mr}$ Gray, to be distinct from other members of the genus. The usual objections to the description of species in isolation are reinforced in the case of the Kosciusko flora by the likelihood that the "new" species may be found elsewhere in the high-altitude and/ or high-latitude flora of the Southern Hemisphere, perhaps well-known elsewhere by another specific or even generic name.

The significance of the Kosciusko flora rests mainly on its relationship to similar floras elsewhere. This was recognized by J. D. Hooker (1860), and the explanation of this similarity has exercised the minds of botanists and plant geographers ever since. A comparative study of floras has been handicapped by an imperfect knowledge of the relevant plant groups involved, few of which have been studied over their whole distribution. At present there is an increasing contact between botanists of the relevant areas but the practical barriers of inter-landmass botany remain. As is usually the case in scientific matters, speculation has gone far ahead of available facts. This is unfortunate if it gives rise to rival schools of thought (Wardle, 1978) rather than disinterested enquiry.

The study of the complex relationships between the Kosciusko flora and other high-altitude and high-latitude floras has been handicapped by the lack of a summary of present knowledge of the taxa of the Kosciusko region. The recently published "Kosciusko Alpine Flora" (Costin et al., 1979), which deals with the southern part of the alpine section of the Kosciusko area under review here, has done much to correct many false notions about the distribution of our species. It is to be hoped that the present study, extending the area covered to include the northern alpine mountains and the extensive subalpine areas from the Victorian border to Happy Jacks Plain (see map, inside back cover) will dispel other false notions.

Botanists may be tempted with a work of this nature to quantify the information assembled. However, the figures extracted in this way will suffer from being based on one person's current botanical opinions. These figures are vulnerable to alteration with the slightest change of botanical interpretation of this group of plants whose relationships, and hence the definition and delimitation of its taxa, are little understood. Whether a species is congeneric with a South American species, conspecific with a Northern Hemisphere species, native or introduced, or can be separated subspecifically from a montane taxon, etc., is a matter for subjective decision in each case. These decisions have usually been made piecemeal over 150 years of botanical study of the flora in the area, and have rarely been made with a 
sound knowledge of the world's population of the group. Notable exceptions to this occur in Oreomyrrhis (Mathias \& Constance, 1955), Epilobium (Raven \& Raven, 1976) and Euphrasia (Barker, unpubl. thesis, 1974). To the best of my knowledge no surveys have ever been made with an eye to aligning comparable biogeographical groups. One continent's subspecies may well be our species, one genus' subspecies another's species, or vice versa.

According to the present work there are 377 species native to the region and 70 introduced by man or the agency of man. In the key I have indicated the introduced taxa with an asterisk. Of the native species, 23 are endemic to the Kosciusko area. The majority of these endemic species are not obligate alpines; many are low-subalpine species in groups not readily recognized by collectors. It is likely therefore that they are not all restricted to this area but may also be found in equivalent parts of Victoria and New South Wales. Asteraceae, a family known to have spread and speciated recently and rapidly, provides 8 of the endemics. The history of most other groups providing endemic species or subspecies must await further study, the origins of these being linked with other continental floras and the time and direction of migration of their antecedents being unknown or controversial. Perhaps the Apiaceae will provide a rewarding area of study. It seems to have invaded the Southern Hemisphere, at least in part through South America, in two waves, the ancient Hydrocotyloideae with both paleoantarctic and more recent antarctic distributions (Hydrocotyle, Dichosciadium, Schizeilema, Oschatzia and Diplaspis), and the later Apioideae (Oreomyrhis, Gingidia and Aciphylla). Both groups are significant in the high-altitude floras of mainland Australia, Tasmania, New Zealand and South America.

I have listed 22 obligate alpine species. This number, like that of the endemics; is likely to be reduced as more and more "alpines" are found to descend cold-airdrainage valleys. Again, most of these species are not easily recognized by collectors and, as the flora becomes better known, they may well be found outside the habitat to which they are now thought to be confined. I have collected at quite low subalpine levels, species which have always been assumed to be restricted to alpine levels. Some of these "out-of-place" species, e.g., Ranunculus niphophilus and Craspedia spp., may have been moved mechanically by water (and in some cases have been observed not to persist); others, e.g. Chionochloa frigida, are gradually moving out from refugia where they were protected from stock; many however have just never been sought or recognized away from their accepted stereotyped niche. Endemism is not necessarily a characteristic of obligate alpines, some of the species of most restricted habitat being also found in New Zealand. Many have not yet been critically compared with material from other Southern Hemisphere alpine habitats. I cannot accept the suggestion that any one of these restricted species is likely to have been introduced from New Zealand by man, with the possible exception of Uncinia sinclairii which is known only from a locality frequented by tourists. So many facts about Uncinia in Australia have come to light in recent years that I am keeping an open mind about this collection at present.

Plants recently introduced to the region include a higher ratio of dicotyledonous to monocotyledonous species than is found in the native flora. Perhaps many monocots were so well suited to the area that they made the journey on their own long before white man and the adventives arrived. Few of these adventives which have come in stock and stock-feed, as plantings to reduce erosion, or as part of the increasing roadside variety brought by service and tourist vehicles, have had much effect on undisturbed areas, and though the numbers of species and of individuals, are increasing adventives are becoming more restricted in the area of their occurrence. Only Acetosella, which so often marks old sheep-camps, and Spergularia, usually on bare gravel, appear to have a significant place in the alpine flora.

Some species are doubtfully native. Decision about some of these must await a thorough biogeographical and taxonomic study. Two studies of this nature have 
confirmed that Sagina procumbens (Crow, 1978) and Alchemilla xanthochlora (Rothmaler, 1955) are introduced. Veronica serpyllifolia may have both a native and an introduced element, but its position at present is uncertain, as is that of several other species having apparently bipolar distributions.

The distribution given for each species in this key is based on the most recent information available, together with a survey of material in the collection of the National Herbarium of New South Wales. Altitude is a most significant factor in the distribution of these species. It has not always been possible to confirm the authenticity of records from other countries or even other States of Australia, but in general those few species which extend to Western Australia and South Australia are either widely distributed across the southern part of Australia or almost ubiquitous. On the other hand, many species extend southward and northward, the northward extent varying according to the availability of suitable conditions. Especially well-represented in the groups extending northward are high-altitude swamp species. These are often found at Barrington Tops, and elsewhere on the Northern Tablelands, and may even extend to New Guinea or beyond into Asia. The parallel between the distribution of these species and the migration routes of a number of birds of such situations (Frith, 1976a and 1976b) is surely more than coincidental. It is recognized that birds are not frequent visitors to alpine Kosciusko (Frith, 1976a), but in high summer, the time when seeds are readily available, there are always a few birds of swampy habitats, ducks, snipe, etc., visible to the casual observer; certainly enough to provide occasional transport for propagules.

\section{THE ORIGIN OF THE KOSCIUSKO FLORA}

The flora now inhabiting Kosciusko must have arrived in this region after the PlioPleistocene glaciation, uplift and erosion had caused displacement of the previous flora. The Plio-Pleistocene period of change had great significance for the biota of the whole world. In the Southern Hemisphere it was only then that uplift provided opportunity for the spread and evolution of high-altitude taxa. This uplift was virtually simultaneous in South America, New Zealand, Australia, Malesia and New Guinea, and it was only with this uplift that migration routes became available for Northern Hemisphere high-altitude and high-latitude taxa through southeastern Asia (Raven, 1973) and South America.

At the beginning of the Cretaceous period Southern Hemisphere landmasses were assembled in the southern continent Gondwanaland, where, in the region later to include the Kosciusko massif, a moist temperate forest was dominant, and subalpine and alpine habitats absent. This moist temperate forest, characterised by the genus Nothofagus, remains in South America, New Zealand, Tasmania and New Caledonia, and has spread to New Guinea. It was once more widespread in eastern mainland Australia than the present surviving pockets would suggest. Its presence on the Southern Tablelands of New South Wales in the Quaternary is shown in paleobotanical studies surveyed by Bowler et al. (1976). Nothofagus was present in the Kosciusko area, on the Toolong Range, until 35,000 years ago, after which cold and subsequent drier conditions eliminated it and prevented its return.

It is unfortunate that a common origin in Gondwanaland is so often used to explain striking similarities in some groups common to the high-mountain floras of the southern lands. It was bearing its part of the temperate flora of the old Pacific coast of Gondwanaland that New Zealand separated from that supercontinent approximately 80 million years ago (Raven, 1973), and not until the Plio-Pleistocene period, less than 2.5 million years ago, would conditions have allowed a high-altitude flora to develop there. When the origin of the southern high-altitude floras is sought, we must surely look to floras other than that of Gondwanaland for the immediate antecedents of present taxa. We must suspect an origin in Gondwanaland for a genus such as 
Astelia, which is often associated with Nothofagus forests and occurs now in a temperate forest habitat in southeastern Victoria and northeastern New South Wales, but our present-day high-altitude Astelia species are just as likely to have migrated recently from another high-altitude area as to have evolved from the temperate forest species formerly existing in our region. The resemblance between the flora of Kosciusko and that of the high mountains of New Zealand (Mark \& Adams, 1973) is intriguing. Some of these species could represent endpoints of lines of evolution from an ancestor inhabiting Gondwanaland, and others are more directly related, having crossed the Tasman Sea between two moist temperate forest floras before the Kosciusko uplift. However, most undoubtedly crossed the gap of now more than $1500 \mathrm{~km}$, between the Australasian landmasses, by long-distance dispersal, in postglacial times. The fact that many of the species common to both countries, e.g. Scleranthus biflorus and Crassula helmsii (which are found on sea-coasts in New Zealand), do not seem to have found identical niches negates the suggestion that selection pressure has kept them alike for a long time; instead it indicates recent migration.

Over the last 80 million years, and especially the last 30 million, with strengthening westerly winds (Raven, 1973), long-distance dispersal of high-altitude taxa from west to east has been a continuing process. The constant bombardment of New Zealand with western taxa over the millennia seems the only possible explanation for its complement of flora and fauna, so much of which seems to have evolved from the survivors of over-, on- or under-oceanic travel. This opinion is supported by much of the zoogeographic information by contributors to "Biogeography and Ecology in New Zealand" (Kuschel, 1975). Raven's view that much of the high-altitude flora entered the Southern Hemisphere during and after the late Pliocene from Asia is credible, though I believe a route through South America for some groups to be a probability. Having reached the higher latitudes, these taxa have circulated, colonizing the new habitats becoming available and often speciating rapidly in these areas of evolutionary opportunity. Some groups have circulated south of mainland Australia, or have become extinct here, others have reached southern Australia and travelled northward to New Guinea, and even Malesia and eastern Asia, while a few are now extending northward through South America, e.g. Colobanthus (Raven, 1973). There is at present little information to show how and when the majority of plant groups reached the Southern Hemisphere or how they have evolved and become distributed since.

Both New Zealand and Kosciusko have examples of groups which have evolved explosively as new niches formed. At Kosciusko the differences between the new taxa are subtle and in many cases still await elucidation. Some of the taxa now considered polymorphic, such as Celmisia asteliifolia, may well prove with further examination to consist of distinct species, each with its own habitat, as do the now-recognized species of Poa (Vickery, 1970), Ranunculus (Briggs, 1959) and Craspedia.

It seems that, at least in some groups in the Kosciusko flora, diversification has been recent; how recent is a matter for conjecture. Owing to the drastic geological and climatic changes that have affected the area, much of the flora of Kosciusko could be relatively young, evolving into the new niches provided as the last ice retreated. Under the disturbed conditions prevailing after the advent of grazing, especially the trampling of bogs and late-season burning, a lack of sterility barriers between many species became evident, and a number of genera produced abundant hybrids. The most conspicuous among these genera, according to my earliest observations, were Ranunculus (see Briggs, 1962) and Craspedia. With the more settled conditions now, these hybrids are no longer a conspicuous feature of the vegetation. In contrast to this, other genera have been found to retain hybrids under the more stable conditions; in this group are Luzula and Oreomyrrhis. In each of these genera a pair of species, each partner of which must be recognized as distinct when found in its specialized habitat, 
breaks down so completely that much of the material is impossible to place. It could therefore be assumed that the breakdown of an ecological barrier established in an earlier period has occurred, following a more recent climatic or geological change. As the flora stabilizes and becomes better known, further examples of both patterns will probably be revealed, and it may soon become possible to recognize distinct species which are now confused by a puzzling assortment of intermediate forms.

At present few of the taxa included here have been studied thoroughly, and little of the comparative cytological work which might indicate ancestral areas has been undertaken. In most groups we must assess whether our predecessors were correct in deciding whether plants were conspecific either side of oceans, or whether generic limits have been adequately defined. It is uncertain which groups were in Gondwanaland, let alone whether any survived the Plio-Pleistocene vicissitudes so as to be recognizable today. Few South American groups have been studied by workers familiar with Australasian members of those groups and, as Mathias \& Constance (1971) indicate, such a study may cause some rethinking.

\section{THE DISTRIBUTION OF THE FLORA}

The biogeographical pattern in Australia for Kosciusko plant taxa is often similar for a number of unrelated groups. This similarity is independent of the age of the group, i.e. whether it has evolved recently, e.g. subspecies and species of the Asteraceae, or could have been present in the Tertiary or earlier. It also seems to be independent of the floristic element to which the taxon belongs.

Many Kosciusko plant groups must be considered to belong to the floristic element associated with the high latitudes of the Southern Hemisphere, but as well as these Antarctic elements, both ancient and of a more recent order, there is a strong element of the more scleromorphic Australian flora at Kosciusko especially at subalpine levels. This element gives the characteristic Australian appearance to much of the region. These groups, e.g. members of Myrtaceae, Proteaceae, Mimosaceae and Rutaceae, have probably been able to invade the Kosciusko area successfully because they are tolerant of the edaphic conditions there, well-represented in the surrounding montane flora, and can survive the summer atmospheric conditions found at Kosciusko, an area where the summer atmosphere is drier than in many other highmountain areas. The fact that Kosciusko has a much drier summer climate than most other southern alpine areas, especially those of western Tasmania and south-western New Zealand may explain its lack of some of those species which have successfully migrated to the fiordland of New Zealand from South America and Western Tasmania. Extinction, as drier conditions developed and as a well-established and wellsuited dry-country flora was able to invade, may have played an important part in determining the present composition of our high-altitude flora. McVean (1969) has said that the Kosciusko alpine region is floristically poor, though it must be taken into account that he published this opinion before a number of segregate species in important genera were recognized.

The present climate of this area is discussed in detail by Costin (1954). The fact that most precipitation (largely as snow) is in winter, the summer rainfall being erratic, helps to account for the difference between this and other mountain floras. In order to survive, the species of the Kosciusko area must, in their main growing period, face extremes of climate: e.g. erratic snowfalls, extremely heavy summer thunderstorm rains, strong winds, hail, frosts and, more especially, prolonged spells of hot, dry and cloudless days. These factors have a significant effect on some species of this predominantly perennial flora, and cause the readily observed short-term cyclical changes in the vegetation. This variation in the predominating species, combined with change resulting from the recovery of the vegetation from grazing, makes it difficult to assess the "natural state" of the area before white settlement. This difficulty is 
increased by the continuing deterioration in some areas where grazing has upset the precarious soil-balance, and where there is increased disturbance associated with the use of the region as a national park and for winter recreation.

Reduced interference over most of the region, greater sophistication of management of the necessarily disturbed areas, and increased protection from fire, seem to be bringing a greater stability than has been known during the 125 year period of botanical study of the area. Costin (1954) presented a picture of Kosciusko in its darkest hour. Time and wise management will assure a return to a more steady state, but it seems unlikely that this state will be identical with that existing before white man brought his vast and destructive influence to bear on the region.

\section{ACKNOWLEDGEMENTS}

My thanks are due to many people who have been associated, knowingly or unknowingly, with this work, and who have contributed a great deal to my knowledge, understanding and love of this fascinating area; to the late Dr Joyce Vickery and the late Dr Marie (Betty) Phillips for their example and encouragement; to Mr Max Gray, always so helpful and co-operative; to my colleagues at the National Herbarium of New South Wales, so readily available for consultation and discussion; to Mrs Jennifer Simons who has shared much of the field work with me and to the members of my family who have freely provided companionship and understanding. To this list must be added all those people who have written about this area and its problems or about these plant groups or associations of plant groups and who, by their writings, have greatly assisted me to form my opinions. Of particular help has been the work of Dr P.H. Raven, on biogeography and Epilobium, Dr M.E. Mathias and Dr L. Constance, on Southern Hemisphere Apiaceae, Dr A.F. Mark, on the New Zealand highmountain flora, and $\operatorname{Dr}$ A.B. Costin whose classic early work, 'A study of the Ecosystems of the Monaro Region', forms such a sound basis for scientific study in the high-mountain areas of New South Wales.

\section{REFERENCES}

Barker, W.R. (1974). A taxonomic revision of Euphrasia L. (Scrophulariaceae) in Australia. Univ. of Adelaide, unpubl. thesis.

Bowler, J.M., Hope, G.S., Jennings, J.N., Singh, G. and Walker, D. (1976). Late Quaternary climates of Australia and New Guinea. Quaternary Res. 6: 359-394.

Briggs, B.G. (1959). Ranunculus lappaceus and allied species of the Australian mainland. I. Taxonomy. Proc. Linn. Soc. New South Wales 84: $295 \times 324$.

Briggs, B.G. (1962). Interspecific hybridization in the Ranunculus lappaceus group. Evolution 16: 372-390.

Costin, A.B. (1954). 'A Study of the Ecosystems of the Monaro Region of New South Wales.' (Government Printer: Sydney.)

Costin, A.B., Gray, M., Totterdell, C.J. \& Wimbush, D.J. (1979). 'Kosciusko Alpine Flora.' (CSIRO: Melbourne, and Collins: Sydney.)

Crow, G.E. (1978). A taxonomic revision of Sagina (Caryophyllaceae) in North America. Rhodora 80: 42.

Frith, H.J. (ed.) (1976a). 'Birds in the Australian High Country.' Revised edn. (Reed: Sydney, Wellington, London.)

Frith, H.J. (ed.) (1976b). 'Readers Digest Complete Book of Australian Birds.' (Readers Digest Services: Sydney.)

Helms, R. (1893). Report on the grazing leases of the Mt Kosciusko plateau. Agric. Gaz. New South Wales 4: 530.

Hooker, J.D. (1860). Introductory Essay. 'Flora Tasmaniae.' (Lovell Reeve: London.)

Kuschel, G. (ed.) (1975). 'Biogeography and Ecology in New Zealand.' (Junk: The Hague.) 
McVean, D.N. (1969). Alpine vegetation of the central Snowy Mountains of New South Wales. J. Ecol. 57: 67-86.

Maiden, J.H. (1898). A contribution towards a Flora of Mt Kosciusko. Agric. Gaz. New South Wales 9: 720.

Mark, A.F., \& Adams, N.M. (1973). 'New Zealand Alpine Plants.' (Reed: Wellington.)

Mathias, M.E. \& Constance, L. (1955). The genus Oreomyrrhis. Univ. Calif. Publ. Bot. 27: 347-416.

Mathias, M.E., \& Constance, L. (1971). A first revision of Huanaca. Kurtziana 6: 7-23.

Raven, P.H. (1973). Evolution of subalpine and alpine plant groups in New Zealand. New Zealand J. Bot. 11: 177-200.

Raven, P.H., \& Raven, T.E. (1976). The genus Epilobium (Onagraceae) in Australasia: A systematic and evolutionary study. New Zealand DSIR Bull. No. 216: 1-321.

Rothmaler, W. (1955). Alchemilla und Aphanes in Australien. Feddes Repert. Spec. Nov. Regni Veg. 58: 307.

Vickery, J.W. (1970). A taxonomic study of the genus Poa L. in Australia. Contr. New South Wales Natl. Herb. 4: 145-243.

Wardle, P. (1978). Origin of the New Zealand mountain flora, with special reference to trans-Tasman relationships. New Zealand J. Bot. 16: 535-550.

Wimbush, D.J., \& Costin, A.B. (1979). Trends in vegetation at Kosciusko. Austral. J. Bot. 27: 741-871.

\section{KEY TO THE FAMILIES}

(This is an artificial key based only on species occurring in the area. An index to the families is given on p. 297.)

1. Plant bearing spores. PTERIDOPHYTA (ferns and fern allies).

2. Plant rooted in mud or shallow water. ISOETACEAE (page 234)

2.* Plant growing in soil or on rocks.

3. Sporangia solitary and axillary.

3.* Sporangia on the lower surface or margin of the lamina.

4. Sporangia without an annulus.

OPHIOGLOSSACEAE

(page 234)

4.* Sporangia with an annulus.

5. Fronds delicate and translucent, usually one cell thick. Annulus not interrupted by the pedicel HYMENOPHYLLACEAE

(page 234)

5.* Fronds robust, or, if rather delicate, then not one cell thick. Annulus interrupted by the pedicel.

6. Sori exindusiate. Lamina simple.

6. Sori indusiate. Lamina compound.

7. Sori elongated into vascular commisures parallel to the costa. 
8. Ovules borne naked on the surface of ovuliferous scales. GYMNOSPERMAE (conifers).

8.* Ovules enclosed in carpels. ANGIOSPERMAE.

9. Embryo with one cotyledon. Flowers usually trimerous or with the perianth much reduced; often grouped in spikelets. MONOCOTYLEDONEAE.

10. Ovary superior or perianth absent or obscure.

11. Perianth petaloid and often coloured; if inconspicuous and not coloured, the fruit a berry.

11.* Perianth absent or, if present, not petaloid. Fruit not a berry.

12. Flowers with regular perianth-segments; small but not obscured by bracts.

13. Perianth-segments 4 . POTAMOGETONACEAE (page 235)

13.* Perianth-segments 6. JUNCACEAE (page 249)

12.* Flowers with perianth-segments minute or absent; bracteate and arranged in spikelets.

14. Each flower with 2 bracts, one above and one below. POACEAE

14.* Each flower with one subtending bract.

15. Leaf-sheaths usually closed. Anthers 2-locular.

15.* Leaf-sheaths open. Anthers 1-locular.

10.* Ovary inferior. Perianth well-developed.

9.* Embryo with 2 cotyledons. Flowers rarely trimerous. DICOTYLEDONEAE.

16. Plant woody, though often low-growing or even prostrate.

17. Flowers irregular.

18. Flowers with 5 petals modified as a standard, 2 wings and a keel.

FABACEAE (page 264)

18.* Flowers not as above.

19. Flowers with 2 sepals resembling petals, 2 lateral petals and a third petal forming a keel.

19.* Flowers not as above.

20. Stigma enclosed in a cup-like indusium.

GOODENIACEAE (page 284)

20.* Stigma not as above.

21.* Ovary with 2 or more loculi.

22. Fruit beaked, with 5 mericarps separating at the base at maturity

22.* Fruit not as above.

23.* Fruit a 2-locular capsule 
24. Plant armed with prickles.

24.* Plant not armed with prickles.

25. Plant rigid, with spiny branches.

25.* Plant not as above.

26. Leaves reduced to scales. Fruit on a fleshy red receptacle.

26.* Leaves and fruit not as above.

27. Stipules membranous and united to form a sheath around the stem

27.* Stipules, if present, not united around the stem.

28. Plant aromatic, with oil-glands in the leaves.

29. Petals 2

29.* Petals more than 2 .

30. Fruit a capsule MYRTACEAE (page 270)

30.* Fruit separating into 1 -seeded mericarps. RUTACEAE (page 267)

28.* Plant not aromatic and without oil-glands in the leaves.

31. Ovary inferior.

32. Leaves simple, opposite. RUBIACEAE (page 282)

32.* Leaves compound, alternate. ARALIACEAE (page 273)

31.* Ovary superior.

33. Ovary 1-locular.

34. Fruit a legume MIMOSACEAE (page 263)

34.* Fruit not a legume.

35. Fruit succulent. PROTEACEAE (page 254)

35.* Fruit not succulent. THYMELAEACEAE (page 269)

33.* Ovary with 2 or more loculi.

36. Fruit with 5 loculi. EPACRIDACEAE (page 275)

36.* Fruit with 2 loculi.

36a. Stamens 2-4 SCROPHULARIACEAE (page 279)

36a.* Stamens 5 PITTOSPORACEAE (page 262)

16.* Plant herbaceous.

37. Flowers in simple or compound capitula, the calyx absent or forming a pappus on the inferior fruit.

37.* Flowers not as above.

38. Flowers irregular. 
39. Flowers with 5 petals, modified as a standard, 2 wings and a keel

39.* Flowers not as above.

40. Anthers fused with the style to form an irritable column with a trigger-like action.

40.* Anthers free or if united then free from the style.

41. Plant of wet places; with submerged modified leaves bearing small bladders.

41. Plant not as above.

42. Fruit a 1-locular capsule with 3 valves.

42.* Fruit with 2 or more loculi.

43. Fruit beaked, with 5 mericarps separating at the base at maturity....

43.* Fruit not as above.

44. Stigma enclosed in a cup-like indusium GOODENIACEAE (page 284)

44.* Stigma not as above.

45. Fruit a capsule with 2 loculi. SCROPHULARIACEAE

45.* Fruit not a bilocular capsule.

46. Stamens 4 or 2. Stems often quadrangular in cross-section

46.* Stamens 5. Stems not quadrangular.

47. Stamens epipetalous. Plant conspicuously hispid

BORAGINACEAE

(page 278)

47.* Stamens with anthers connate around the style. Plant not conspicuously hispid

38.* Flowers regular.

48. Leaves covered with sticky irritable glandular hairs

48.* Leaves not as above.

49. Leaves alternate or radical.

50. Ovary inferior.

51. Flowers, predominantly blue or purple, usually campanulate.

51.* Flowers not as above.

52. Flowers usually in simple or compound umbels; fruit separating into 1 -seeded mericarps

52.* Inflorescence and fruit not as above.

53. Leaves pinnate, fan-shaped or reniform. ROSACEAE

53. Leaves not as above 
54. Ovary 1-locular or the carpels free.

55. Stipules membranous and united to form a sheath around the stem.. POLYGONACEAE (page 255)

55.* Stipules, if present, not as above.

56. Sepals 2 PORTULACACEAE (page 256)

56. ${ }^{*}$ Sepals 4 or 5 .

57. Stamens perigynous ROSACEAE (page 262)

57.* Stamens hypogynous.

58. Stamens inserted on a disc. Flowers in a spike-like inflorescence RESEDACEAE (page 261)

58.* Stamens and flowers not as above RANUNCULACEAE (page 258)

54.* Ovary with 2 or more loculi.

59. Ovary with 2 or 4 loculi.

60. Plant creeping and rooting at the nodes CONVOLVULACEAE (page 277)

60.* Plant not as above.

61. Fruit a circumcissile capsule PLANTAGINACEAE (page 281)

61.* Fruit not as above.

62. Ovary breaking into 4 articles at maturity BORAGINACEAE (page 278)

62.* Ovary not as above.

63. Petals fused at least at the base SCROPHULARIACEAE (page 279)

63.* Petals free BRASSICACEAE (page 260)

59.* Ovary with 3 or 5 loculi.

64. Ovary 3-locular.

65. Corolla and calyx tubular STACKHOUSIACEAE (page 268)

65.* Corolla and calyx not tubular EUPHORBIACEAE (page 268)

64.* Ovary 5-locular.

66. Fruit beaked, with 5 mericarps separating at the base at maturity GERANIACEAE (page 266)

66. Fruit not as above.

67. Leaves trifoliolate OXALIDACEAE (page 267)

67.* Leaves simple.

68. Flowers with an epicalyx of bracteoles at the base of the calyx

68.* Flowers with an unadorned calyx 
69. Ovary inferior.

70. Flowers predominantly blue or purple and usually campanulate

70.* Flowers not as above.

71. Fruit a capsule ONAGRACEAE (page 272)

71.* Fruit not a capsule.

72. Stipules absent or rudimentary HALORAGACEAE (page 273)

72.* Stipules obvious; usually on the stem between the leaf-bases RUBIACEAE (page 282)

69.* Ovary superior.

73. Flowers trimerous

ELATINACEAE (page 269)

73.* Flowers with 4 or 5 sepals and petals or calyx- and corolla-lobes.

74. Carpels 3-6, free or connate only at the base CRASSULACEAE (page 262)

74.* Carpels not as above.

75. Ovary 5-locular. Flowers yellow OXALIDACEAE (page 267)

75.* Ovary usually 1- or 2-locular; if 5-locular then the flowers not yellow.

76. Fruit a 2-locular capsule.

77. Stamens epipetalous, alternating with the corolla-lobes. Style splitting into 2 LOGANIACEAE (page 277)

77.* Stamens not as above. Style simple SCROPHULARIACEAE (page 279)

76.* Fruit a 1-locular capsule or nut.

78. Flowers orange-yellow HYPERICACEAE (page 268)

78.* Flowers not orange-yellow.

79. Flowers white with purple stripes GENTIANACEAE (page 277)

79.* Flowers not as above.

80. Sepals 2 PORTULACACEAE (page 256)

80.* Sepals or calyx-lobes $4-5$ .CARYOPHYLLACEAE (page 256)

\section{PTERIDOPHYTA}

The arrangement of taxa adopted here is that of Crabbe, Jermy \& Mickel in Fern Gazette 11: 141 (1975).

\section{LYCOPODIACEAE}

\section{Lycopodium $\mathrm{L}$.}

1. Sporangia in terminal strobili on slender peduncles L. fastigiatum $\mathrm{R}$. Br.

Widespread and common. Usually near rocks. [In cool mountain areas of all eastern States and in N.Z.] 
1. * Sporangia borne in the upper leaf-axils L. australianum (Herter) Allan

Widespread, in damp areas near rocks. Apparently not common, but in subalpine areas usually completely hidden by overhanging shrubs. [In Tas., Vic., N.Z. and Indonesia but not found elsewhere in N.S.W.] The generic position of this taxon is at present under review. This species is referred to Huperzia Bernh., as $H$. selago (L.) Bernh. ex Schrank et Mart., by M. Gray in Costin et al., Kosciusko Alpine Flora (1979).

\section{ISOETACEAE}

Isoetes L.

I. muelleri A. Br.

Found only at Betts Creek, c. $1750 \mathrm{~m}$, in still water. [Occurring throughout Australia.]

\section{OPHIOGLOSSACEAE}

Ophioglossum L.

O. Iusitanicum L. ssp. coriaceum (A. Cunn.) Clausen

Found on Happy Jacks Plain, in Snowgum woodland. [Widespread in Australia. Also in N.Z. and S. America.] The species extends to the N. Hemisphere.

\section{HYMENOPHYLLACEAE \\ Hymenophyllum Sm.}

H. peltatum (Poir.) Desv.

Rare, perhaps only along the Ramshead slopes above the Thredbo R., and not reaching alpine areas. On rock faces. [Also at high altitudes elsewhere in N.S.W. and in Tas., Vic., Qld and N.Z., and extending to S. Africa.]

\section{GRAMMITIDACEAE \\ Grammitis Swartz}

G. armstrongii Tindale

Scattered, not common. Usually forming dense masses in vertical crevices of boulders. [Not found elsewhere in N.S.W. but in Tas, Vic., N.Z. and subantarctic islands.] This species may be conspecific with $G$. poeppigiana (Mett.) Pic.Ser., in which case $G$. poeppigiana has priority.

\section{ASPLENIACEAE}

1. Sori oblong or linear. Asplenium 1.

1.* Sori circular.

2. Plants delicate. Stipes with 2 vascular strands at the base, joining upwards to form a more or less U-shaped bundle Cystopteris 2.

2.* Plants robust. Stipes with several vascular strands near the base 


\section{Asplenium L.}

A. flabellifolium Cav.

Widely scattered but not common. Usually in rock crevices. [Widespread in forests of eastern N.S.W., in all other States and in N.Z.]

2. Cystopteris Bernh.

C. fragilis (L.) Bernh. sens. lat.

Widely scattered and rare, in shady rock crevices. [Not found elsewhere in N.S.W. but in Tas., Vic. and N.Z.; almost cosmopolitan.] Pichi Sermolli, in Cytotaxonomical Atlas of the Pteridophyta: 272 (1977), has referred the Australasian representative of this widespread taxon to $C$. tasmanica Hook. I have not adopted the double specific epithet, flix-fragilis, and accept the argument against this usage given by Weatherby in Rhodora 28: 129 (1926).

\section{Polystichum Roth}

P. proliferum (R. Br.) Presl

Widespread and common. Usually among rocks. [In Tas., eastern N.S.W. and Vic., and probably extending to S. Qld.]

\section{BLECHNACEAE \\ Blechnum L.}

B. penna-marina (Poir.) Kuhn

Widespread and common. Usually along watercourses and among rocks. [In N.S.W. extending to the N. Tlds, and also in Tas., Vic., N.Z., subantarctic islands and $\mathrm{S}$. America.]

\section{GYMNOSPERMAE}

\section{PODOCARPACEAE}

Podocarpus L'Hérit.

Widespread and common in both alpine and subalpine areas. Associated with rocks and usually stunted to spread over their surface, rarely a small tree. [Found elsewhere in southeastern N.S.W. and also in Tas. and Vic.]

\section{ANGIOSPERMAE† \\ MONOCOTYLEDONEAE \\ POTAMOGETONACEAE \\ Potamogeton L.}

P. ochreatus Raoul

In Diggers Creek Reservoir, $1640 \mathrm{~m}$. [Widespread in Australia and extending to N.Z. and Asia.]

$\dagger$ An asterisk * beside a name denotes an introduced genus or species. 


\section{POACEAE}

1. Spikelets with 1 fertile floret and with or without 1 or 2 male or sterile florets below it.

2. Spikelets with 2 or 3 florets, the terminal floret bisexual and with 1 or 2 sterile or male florets below.

3. Spikelets with 2 florets, the upper bisexual, the lower usually staminate and with a geniculate awn...........................Arrhenatherum 8.

3.* Spikelets with 3 florets, one bisexual and terminal with 2 male florets or 2 sterile lemmas below. Plant often smelling of coumarin.

4. Panicle open, without awns. Lower florets staminate Hierochloe 1.

4.* Panicle spike-like and awned. Lower florets reduced to lemmas... Anthoxanthum 2.

2.* Spikelets with 1 bisexual floret.

5. Lemmas indurated and rigid at maturity. The awn terminal, several times longer than the lemma and usually twisted and geniculate.....

Stipa 3.

5. Lemmas hyaline to indurated at maturity but if indurated the awns not terminal.

6. Spikelets with truncate awned glumes and tightly packed in spikelike cylindrical panicles

6.* Spikelets with glumes not truncate and awned. Panicles spreading or dense.

7. Lemmas very thin and often shining; glabrous or softly hairy... Agrostis 5.

7. * Lemmas chartaceous to indurated, usually scaberulous or scabrous and never completely smooth and shining.

8. Lemmas lanceolate to broad-oblong, usually \pm indurated at maturity and usually toothed at the apex. The awn, if present, not twice as long as the lemma Deyeuxia 6.

8. ${ }^{*}$ Lemmas linear to narrowly linear-lanceolate, entire or minutely notched. The awn at least twice as long as the lemma.

Dichelachne 7 .

1.* Spikelets with 2 or more fertile florets or, if with 1 fertile floret then with sterile florets above it.

9. Lemmas with a geniculate awn from the back, or from the sinus of a 2-lobed tip; or minutely 3-lobed at the apex.

10. Florets 2, the lower bisexual and awnless, the upper male and awned Holcus 9.

10.* Florets 2, or 3, or more, all alike and bisexual.

11. Lemma awned from the back.

12. Florets 2 Aira 10.

12.* Florets 3 . 
13. Panicles dense and spike-like. Awns geniculate and shortly exserted from the glumes.

Trisetum 11.

13.* Panicles spreading. Awns straight and mostly included within the glumes. Deschampsia 12.

11. $*$ Lemma awned from the sinus of a 2-lobed tip, the lobes often awnlike and the central awn usually geniculate and twisted; or the lemma minutely 3-lobed.

14. Apex of the lemma conspicuously 2-lobed with a central and conspicuous awn.

15. Plant forming large tussocks with the remains of old leaf-bases persisting. Seeds narrow and more than 3 times longer than broad. Chionochloa 13.

15.* Plant and seeds not as above Danthonia 14.

$14{ }^{*}$ Apex of the lemma minutely 3-toothed Erythranthera 15.

9. ${ }^{*}$ Lemmas awnless or with a straight or gently curved, terminal or subterminal awn.

16. Spikelets borne either on a solitary spike or in crowded clusters at the ends of stiff panicle-branches.

17. Spikelets borne in one-sided clusters at the ends of the few, stiffly spreading naked panicle-branches

17.* Spikelets borne on either side of a solitary spike.

18. Spikelets borne edge-wise to the rhachis Lolium 18.

18.* Spikelets borne flat-wise to the rhachis Agropyron 17.

16.* Spikelets in loose or contracted and spike-like panicles.

19. Spikelets borne in clusters of 3 in a contracted spike-like panicle Hordeum 16.

19.* Spikelets borne singly in loose or contracted panicles.

20. Lemmas rounded at the back at least in the lower part.

21. Perennial. Festuca 21.

21.* Annual.

22. Lemmas more than $2 \mathrm{~mm}$ broad, ovary with a hairy terminal appendange above the styles.... Bromus 20.

22.* Lemmas less than $2 \mathrm{~mm}$ broad. Ovary with terminal styles and lacking an appendage.... Vulpia 22.

20.* Lemmas laterally compressed and keeled, or if only slightly keeled then with web-like hairs on the callus Poa 23.

\section{Hierochloe $\mathrm{R}$. Br.}

1. Upper surface of the blade deeply channelled between the close nerves. Spikelets mostly 6-8 mm long .................... r. redolens (Vahl) Roem. \& Schult.

Only one record, from Pretty Point. [In Tas. and Vic., elsewhere in N.S.W. in high moist places, extending to Barrington Tops, and in N.Z., N. Guinea and S. America.] 
1.* Upper surface of the blade lightly ribbed but not deeply channelled between the rather more distant nerves. Spikelets 5-6 $\mathrm{mm}$ long

H. submutica F. Muell.

Scattered. At all altitudes, in moist places. [Not found elsewhere in N.S.W. but in Vic.]

\section{2. *Anthoxanthum L.}

*A. odoratum $\mathrm{L}$.

Common in more sheltered and damp subalpine areas. [Widely naturalized in cooler parts of N.S.W. Also in all other States. Native to Europe and temperate Asia.]

\section{Stipa L.}

S. nivicola J.H. Willis

Only in subalpine areas. [Found elsewhere in N.S.W. only at high altitudes. Also in Vic.]

\section{4. *Phleum L.}

Common on road verges especially at low altitudes. [Widely naturalized * $P$. pratense $\mathrm{L}$. in southern Australia. Native to Europe.]

\section{Agrostis L.}

1. Palea present and conspicuous.

2. A tufted annual. Lemmas awned A. aemula $\mathrm{R}$. Br. Subalpine, in sheltered places. [In eastern N.S.W. and all other States, and introduced into N.Z.]

2.* A rhizomatous or stoloniferous perennial. Lemmas unawned.

3. Plants stoloniferous. Panicles usually linear-lanceolate or oblong, contracted after flowering. *A. stolonifera $\mathrm{L}$. Planted, rarely naturalized. [Native to the $\mathrm{N}$. Hemisphere.]

3.* Plants rhizomatous, occasionally stoloniferous. Panicles oblong-ovate to pyramidal and usually open *A. capillaris L.

Planted and naturalized. [Native to the N. Hemisphere.] This species has until recently been known as A. tenuis Sibth.

1.* Palea absent or minute.

4. Lemma usually conspicuously pubescent; broad and very erose at the apex..... A. meionectes Vickery

At all altitudes, probably always in damp soil, especially on the floor of contour terraces. [Not found elsewhere in N.S.W. but in Vic.]

4.* Lemma usually quite glabrous; narrow and usually not conspicuously erose at the apex.

5. Panicle dense, narrow and rather stiff A. muellerana Vickery

In tufts in exposed alpine and higher subalpine places, often on flat rocky tops. [Also in Tas., Vic. and N.Z. but not found elsewhere in N.S.W.]

5.* Panicle not as above. 
6. Lemma conspicuously awned A. venusta Trin.

At all altitudes in moist places. [Also in Tas. and Vic., and, in N.S.W., extending to the N. Tlds.]

6. *emma unawned or with a small inconspicuous awn.

7. Spikelets $<2 \mathrm{~mm}$ long. Panicle few-flowered and pyramidal. Anthers c. $0.3 \mathrm{~mm}$ long.... A. parviflora $\mathrm{R}$. Br. On creek-banks or in creek gravels in subalpine areas. [Also in Tas. and perhaps Vic. and A.C.T. but not found elsewhere in N.S.W.] This is Brown's species in the strict sense. It can be separated from the common species which has been included in this taxon (see $8 .^{*}$ below).

7.* Spikelets more or less than $2 \mathrm{~mm}$ long but if less then the panicle not few-flowered and pyramidal.

8. Anthers $<0.5 \mathrm{~mm}$ long, usually $0.3 \mathrm{~mm}$.

9. Annual. Glumes scabrous to the base of the keel

A. australiensis $\mathrm{Mez}$

In swamps and on creek banks especially in subalpine areas. [Also in Tas. and Vic., and elsewhere on the S. Tlds of N.S.W.]

9.* Perennial. Glumes, if scabrous, not scabrous to the base of the keel

A. sp. (aff. hiemalis (Walt.) N.L. Britton et al. sens. lat.)

At low subalpine levels in moist shady places. [Also in

Vic. and in mountain forests of southern N.S.W.] This species has previously been included in $A$. hiemalis. It does not have the characteristic spikelet-arrangement of $A$. hiemalis sens. str. and is probably an Australian species.

8. Anthers $0.5 \mathrm{~mm}$ or more in length

Widespread in moist places, especially on creek-banks. [Also in Vic. and higher parts of N.S.W., extending to the N. Tlds.] This species has been included in A. parviflora $\mathrm{R}$. Br. but material matching R. Brown's Type is found in the Kosciusko area and appears to be specifically distinct.

\section{Deyeuxia Clar. ex Beauv.}

1. Awn projecting well beyond the apex of the lemma and equal to or longer than the lemma.

2. Awn attached near the top of the lemma

D. brachyathera (Stapf) Vickery

Occasional in subalpine areas. [Also in Tas. and Vic., and in N.S.W. extending to the N. Tlds.]

2.* Awn attached in the middle or lower part of the lemma.

3. Leaf-blade broad, often flat.

4. Leaves keeled at the apex, with a short blunt point. Awn attached near the middle of the lemma D. carinata Vickery

Widespread at all altitudes. [Also in Tas. and Vic. At high altitudes in N.S.W. and probably extending to the N. Tlds.] 
4. ${ }^{*}$ Leaves acute to acuminate. Awn attached towards the base of the lemma D. quadriseta (Labill.) Benth.

Barely reaching subalpine levels. [Widespread in eastern Australia.] This species includes several forms.

3.* Leaf-blade inrolled and subulate D. monticola (Roem. \& Schult.) Vickery

Widespread in grassland and among rocks. [Also in Tas. and Vic., and in higher parts of N.S.W., extending to Barrington Tops.]

1.* Awn not or only slightly projecting beyond the lemma and shorter than the lemma, minute or absent.

5. Panicle loose with the branches naked for some distance at the base..

D. scaberula Vickery

Rare and scattered in subalpine areas. [Also in Tas. and Vic., and extending to the C. Tlds of N.S.W.]

5.* Panicle dense or if rather loose, the spikelets borne from near the base of the shorter branches.

6. Plants stout ....................................................... crassiuscula Vickery

Widespread, among rocks, of ten in crevices. [Also in Vic. and on high peaks of the A.C.T. but not found elsewhere in N.S.W.]

6.* Plants slender.

7. Awn short and inconspicuous D. affinis M. Gray Widespread, in moist places. [Not found elsewhere in N.S.W. but in Vic.]

7.* Awn minute or absent D. sp.

Widespread, in moist places in subalpine areas. [Also in Tas. and Vic., and in high parts of N.S.W., extending to the N. TIds.] This taxon is referred to as $D$. sp. by Burbidge \& Gray, Fl. Austral. Cap. Terr. (1970).

\section{Dichelachne Endl.}

D. micrantha (Cav.) Domin

Occasional in more sheltered subalpine places. [In all States, N.Z. and New Guinea.]

\section{8. *Arrhenatherum Beauv.}

*A. elatius (L.) Beauv. ex J. \& C. Presl sens. lat.

Occasional in disturbed subalpine areas. [In all States. Almost cosmopolitan.] At least some specimens from this area can be referred to var. bulbosum (Willd.) Spenner.

$$
\text { 9. *Holcus L. }
$$

${ }^{*} H$. lanatus L.

Occasional, along roads and in disturbed areas at lower subalpine levels. [In all States. Native to Europe, Asia and N. Africa.]

\section{0. *Aira L.}

*A. caryophyllea $\mathrm{L}$.

Occasional, in disturbed subalpine areas. [A widely naturalized native of Europe, W. Asia and Africa.] 
11. Trisetum Pers.

T. spicatum (L.) Richt.

Widespread and common at all altitudes but especially in moist alpine areas. [Also in Tas. and Vic., and probably elsewhere on high parts of the S. Tlds of N.S.W., and extending to southeastern Qld. Almost cosmopolitan.]

\section{Deschampsia Beauv.}

D. caespitosa (L.) Beauv.

Widespread in wet places. [In southern N.S.W., Tas., Vic. and S.A. Almost cosmopolitan.]

\section{Chionochloa Zotov}

$$
\text { C. frigida (Vickery) Conert }
$$

Common in relatively sheltered rocky areas at all altitudes. Spreading rapidly over open rocky hill slopes as a delayed response to the cessation of grazing. [Endemic.]

\section{Danthonia Lamk. \& DC.}

1. Spikelet usually $>1 \mathrm{~cm}$ long. Central awn spirally twisted at the base.

2. Panicle dense and contracted, ovate to ovate-lanceolate in outline.

3. Palea broad-elliptical.................................................. D. eriantha Lindl. Subalpine in the northern and western part of the area. [Widespread in southeastern Australia.]

3.* Palea linear-lanceolate D. alpicola Vickery

Common in alpine and high subalpine areas, often in rock crevices. [Also in Tas., Vic. and higher parts of the A.C.T. but not elsewhere in N.S.W.]

2.* Panicle not as above.

4. Leaves not rigid, often pilose.

5. Leaves with tubercle-based hairs. Spikelets crowded ....D. pilosa $\mathrm{R} . \mathrm{Br}$.

Subalpine, perhaps only in the northern part of the area. [In all States and N.Z.]

5.* Leaves glabrous or sparsely pilose. Spikelets not crowded.

Subalpine. [In Tas. and Vic., and in N.S.W. extending to the

C. Tlds. Also in N.Z. and N. Guinea.]

4.* Leaves rigid, more or less setaceous, glabrous.....D. nudiflora P.F. Morris

Common, especially in alpine and higher subalpine areas. [In

Tas., Vic., and on high peaks of the A.C.T. but not found elsewhere in N.S.W.]

1. ${ }^{*}$ Spikelets c. $8 \mathrm{~mm}$ long or less. Central awn not spirally twisted at the base.

6. Plants with a long creeping rhizome. Panicle open

D. $\mathrm{sp}$.

On subalpine stream- or lake-margins. [Endemic.]

6.* Plants tufted. Panicle contracted ................................. D. nivicola Vickery

In moist places in alpine and higher subalpine areas. [In Tas., Vic.

and at high elevations in the A.C.T. but not found elsewhere in N.S.W.] 


\section{Erythranthera Zotov}

1. Glumes ovate-lanceolate, acute, $4-6 \mathrm{~mm}$ long. Lemmas \pm hairy Restricted to feldmark near Northcote Pass. [Also in N.Z.]

E. pumila (Kirk) Zotov

1.* Glumes ovate, subobtuse, $2.5-3 \mathrm{~mm}$ long. Lemmas glabrous E. australis (Petrie) Zotov In alpine and higher subalpine areas, in damp places and late snow areas. [Not found elsewhere in N.S.W. but in Tas., Vic. and N.Z.]

\section{6. ${ }^{*}$ Hordeum L.}

*H. glaucum Steud.

On roadsides and reclaimed areas. [Widely naturalized in Australia, perhaps absent from Tas. Native to Europe, Asia and N. Africa.]

\section{Agropyron Gaertn.}

1. Lemma tapering to the awn which is rigid, scabrid and up to $4 \mathrm{~cm}$ long A. scabrum (Labill.) Beauv.

In more sheltered subalpine areas. [Widespread in all States and in Lord Howe Island and N.Z.]

1.* Lemma narrowed into a short pungent awn less than $10 \mathrm{~mm}$ long A. velutinum Nees

At all altitudes. [In Tas., Vic. and on peaks of the A.C.T. but rarely found elsewhere in N.S.W.]

\section{8. * Lolium L.}

Planted and probably somewhat naturalized on roadsides. [Extensively planted and naturalized in all States. Native to Europe, Asia and N. Africa.]

\section{9. *Dactylis L.}

*D. glomerata L.

Common on roadsides and in disturbed areas. [Extensively planted and naturalized in all States, especially in cooler areas. Native in Europe, Asia and N. Africa.]

\section{Bromus L.}

1. Spikelets short and softly hairy. Awn $1 \mathrm{~cm}$ or less in length

*B. hordeaceus L.

Occasional on roadsides and reclaimed areas. [Restricted to cooler parts of Australia. Native to Europe \& W. Asia.]

1.* Spikelets long and scabrous. Awn $>3 \mathrm{~cm}$ long.................. ${ }^{*} B$. diandrus Roth Occasional on roadsides and reclaimed areas. [Widely naturalized in Australia. Native to the Mediterranean region.] 


\section{Festuca L.}

1. Leaf-blades smooth, or rough only near the top..... ${ }^{*} F$. rubra L. ssp. rubra

Planted, and naturalized especially in disturbed subalpine areas. [Widely planted and naturalized in Australia. Native to Europe, Asia and N. America.] The non-rhizomatous ssp. commutata Gaud. has not been found in the area.

1.* Leaf-blades scabrous.

2. Sheaths and culms smooth. Lemmas awned.

3. Leaves $>2 \mathrm{~mm}$ broad, folded. Lemmas keeled F. hookerana F. Muell. ex Hook. f. In moist places in more sheltered subalpine areas. [Also in Tas. and Vic., and in other cool parts of southern N.S.W.]

3.* Leaves $<1 \mathrm{~mm}$ in diameter, inrolled. Lemmas rounded at the back F. asperula Vickery

In moist peaty places in subalpine areas. [Also in Tas. and Vic. Widespread in N.S.W., extending to the N. Tlds.]

2.* Sheaths and culms scabrous. Lemmas unawned F. muelleri Vickery

Often among rocks in sheltered parts of subalpine areas. [Also in Vic., and elsewhere in N.S.W. at high altitudes, extending to Barrington Tops.]

\section{2. *Vulpia Gmel.}

1. Culms usually sheathed to the base of the panicle. Panicle usually curved

In disturbed subalpine areas. [A widely naturalized native of Europe and the Mediterranean region.]

1.* Culms with the panicle well above the sheath. Panicle usually erect....... *V. bromoides (L.) S.F. Gray

In disturbed subalpine areas. [A widely naturalized native of Europe, the Mediterranean region and Africa.]

\section{Poa L.}

1. Small annual with soft herbaceous leaves Europe.]

Infrequent on road verges. [Naturalized in all States. Native to

\section{1.* Perennial.}

2. Panicle linear with short erect branches and few turgid spikelets Limited to alpine and exposed subalpine areas, usually among rocks. [In Tas., Vic and on higher parts of the A.C.T. but not elsewhere in N.S.W.]

2.* Panicle more or less spreading and if contracted then with numerous spikelets.

3. Blades smooth or scabrous on the outer surface but not manifestly pubescent.

4. Blades flat and usually expanded or folded. 
5. Lower leaf-sheaths not purplish. Lemmas glabrous on the internerves.

6. Tall caespitose plants $50-150 \mathrm{~cm}$ in height with light green leaves $P$. helmsii Vickery

In wet places, often on creek banks, at lower subalpine levels. [Also elsewhere on the S. Tlds of N.S.W. and in Vic.]

6. ${ }^{*}$ Rhizomatous plants $10-90 \mathrm{~cm}$ in height, often with dark green leaves ${ }^{*} P$. pratensis $\mathrm{L}$.

Found in enriched places especially at lower subalpine levels. [Widely naturalized in southern Australia. Native to Europe and Asia.]

5.* Lower leaf-sheaths usually \pm purplish. Lemmas pubescent on the internerves near the base $P$. ensiformis Vickery

Widespread but probably limited to subalpine areas. [In southeastern N.S.W. and in Vic.]

4. ${ }^{*}$ Blades closely folded and/or the margins rolled so the blade is more or less angular-terete.

7. Blades smooth to the touch at least in the upper part.

8. Blades usually bright-green. Base of the plant usually pallid.

9. Lemma $2-3.5 \mathrm{~mm}$ long, pubescent all over the back P. hiemata Vickery

Widespread and common especially in high grassland and in subalpine woodland. [Elsewhere on the $\mathrm{S}$. Tlds of N.S.W. and in Vic.]

9.* Lemma 3.5-5.5 mm long, usually glabrous on the internerves $P$. costiniana Vickery

Widespread and common in wet places at all altitudes. [Also in Vic., in other cool parts of the S. Tlds of N.S.W. and probably on the $\mathrm{N}$. Tlds]

8.* Blades usually bluish. Base of the plant purplish

P. fawcettiae Vickery

Widespread and at all altitudes in woodland and grassland. [Also in Vic. and in other high parts of the S. Tlds of N.S.W.]

7.* Blades rough to the touch.

10. Blades very rigid and subulate, of ten erect. Lower sheaths often purplish P. phillipsiana Vickery

Widespread on drier parts of hillsides; reaching high subalpine levels. [Also in Vic. and in other high parts of the S. Tlds of N.S.W.]

10. Blades not or scarcely rigid. Lower sheaths usually pallid.

11. Lemmas glabrous on the internerves P. clivicola Vickery On grassy slopes, apparently only at subalpine levels. [In other high parts of the S. Tlds of N.S.W. and also in Vic.] 
11.* Lemmas pubescent all over the lower back.

.P. sieberana Spreng. var. sieberana

Common in more sheltered subalpine areas. [In Tas. and Vic., widespread in eastern N.S.W. and extending to Qld.] The species has a similar distribution.

3.* Blades densely pubescent.

12. Hairs short, in 2 lengths. Lower sheath-base not purplish. Lemma usually $<3 \mathrm{~mm}$ long $P$. induta Vickery

Ascending to subalpine levels only at Pipers Creek. [In higher parts of N.S.W., extending to the C. Tlds.]

12.* Hairs of uniform length. Lower sheath-base purplish. Lemma 3-4 mm long ............................................... P. petrophila Vickery [Endemic.]

Only in more sheltered parts of subalpine areas. Among rocks.

\section{CYPERACEAE}

1. Inflorescence a loose terminal cluster of narrow, erect, 1-flowered spikelets. The hypogynous bristles plumose Carpha 1.

1.* Inflorescence not as above.

2. Inflorescence a terminal 1 (rarely more)-flowered spikelet. The hypogynous scales persisting after the nut has fallen. Oreobolus 4.

2.* Inflorescence not as above.

3. Female flowers and nut enclosed in a flask-shaped utricle.

4. Fruit with a hooked projecting bristle Uncinia 6.

4. ${ }^{*}$ Fruit without a hooked projecting bristle Carex 7.

3. Flowers not as above.

5. Glumes imbricate and all around the rhachis.

6. Spikelets solitary, terminal and erect, without bracts. Style-base dilated Eleocharis 3.

6.* Spikelets solitary or clustered, terminal but often appearing lateral from the growth of one involucral bract. Style-base undilated Scirpus 2.

5.* Glumes distichous Schoenus 5.

\section{Carpha Banks \& Soland. ex R. Br.}

1. Spikelets $8-10 \mathrm{~mm}$ long. Leaves less than $2 \mathrm{~mm}$ broad. C. alpina $\mathrm{R}$. Br. Alpine. Common in wet, gravelly places. [Also in Tas., Vic., N.Z. and N. Guinea, but not found elsewhere in N.S.W.]

1.* Spikelets c. $15 \mathrm{~mm}$ long. Leaves usually more than $2 \mathrm{~mm}$ broad C. nivicola $\mathrm{F}$. Muell.

Widespread and common in fens, bogs and other wet places. [Not found elsewhere in N.S.W. but in Vic.] 


\section{Scirpus L.}

These species all belong to the section Isolepis; the genus Isolepis $\mathrm{R}$. Br. is soon to be reinstated (K.L. Wilson, Telopea 2(2), in press).

1. Style-branches 2. Spikelets stout, ovate, often $5-8 \mathrm{~mm}$ long.

S. crassiusculus (Hook. f.) Benth.

Widespread and common in wet areas, often in water. [Also in Tas. and Vic., and extending to Qld, N.Z., N. Guinea and Japan.]

1.* Style-branches 3. Spikelets not as above.

2. Stamens in each floret normally 3. Spikelet partly enfolded by the dilated base of the floral bract ............................S. aucklandicus (Hook. f.) Boeck.

Widespread in wet places. [Also in Tas., Vic., Barrington Tops in N.S.W., Qld, N.Z. and N. Guinea.]

2.* Stamen in each floret normally $1-3$. The base of the floral bract not partly enclosing the spikelet.

3. Leaves well-developed.

4. Floral bract shorter than or equal to the culm. Leaves lax. Base of the plant pale or purplish-red.

5. Leaves strap-shaped and scarcely tapering to the broadly rounded apex. Base of the plant often purplish-red...........S. habrus E. Edgar

Widespread in wet places. [Also in Tas. and Vic., and extending to the N. Tlds of N.S.W., N.Z. and perhaps N. Guinea.]

5.* Leaves tapering to a narrowly rounded apex. Base of the plant rarely tinged with purple ...........S. subtilissimus (Boeck.) S.T. Blake In subalpine and occasionally alpine areas, in wet places. [Also in Tas. and Vic., and extending to the N. Tlds of N.S.W., N.Z., N. Guinea and the Philippines.]

4.* Floral bract longer than the very short culm. Leaves not very lax. Base of the plant pale S. montivagus S.T. Blake In alpine and exposed subalpine areas in wet places. [Also elsewhere in the S. Tlds of N.S.W. and in Vic.]

3.* Leaf-blades poorly developed or lacking S. inundatus (R. Br.) Poir. In wet places in more sheltered low-subalpine areas. [Widespread in Australia and extending to Asia, N.Z., Norfolk Island and S. America.]

\section{Eleocharis $\mathrm{R}$. Br.}

1. Spikelet usually $5 \mathrm{~mm}$ long. Uppermost leaf-sheath thickened, dark and mucronate. E. acuta $\mathrm{R}$. Br.

In lower subalpine areas, in water. [Widespread in Australia and extending to N.Z., Norfolk Island and N. Guinea.]

1.* Spikelet usually $5 \mathrm{~mm}$ or less in length. Uppermost leaf-sheath not as above E. pusilla $\mathrm{R}$. Br.

Found only at Diggers Creek Lake. [Widespread in eastern Australia and in N.Z.] 


\section{Oreobolus $\mathrm{R}$. Br.}

1. Leaves trigonous in cross-section and distichous O. distichus F. Muell.

Widespread and common in wet, often peaty, areas. [Also in Tas., Vic., in higher parts of the A.C.T. and on Barrington Tops in northern N.S.W.]

1.* Leaves almost flat and spirally arranged.

2. Leaves with 2 marginal veins on the upper surface and a single midvein below O. oxycarpus S.T. Blake

Widespread in wet places but not common; reaching alpine levels at Gungartan. [Also in Tas., Vic., in higher parts of the A.C.T. and on Barrington Tops in northern N.S.W.]

2.* Leaves with several conspicuous veins on each surface ..... O. pumilio $\mathrm{R}$. Br. Common in alpine and higher subalpine areas, in fens and other wet places. [Also in Tas., Vic., in high parts of the A.C.T. and in N. Guinea.]

\section{Schoenus L.}

1. A tall plant with culms exceeding the leaves ........S. apogon Roem. \& Schult. In swampy places. Not found above the lower, more sheltered, subalpine valleys. [Widespread in eastern States. Also in N.Z.]

1.* A small plant with culms hidden by the longer leaves S. calyptratus Kükenthal In alpine and higher subalpine areas, in wet places. [Not found elsewhere in N.S.W. but in Tas. and Vic.]

\section{Uncinia Pers.}

1. Leaves $<7 \mathrm{~cm}$ long. The sides of the utricle acute and the top bearing short, stiff hairs U. sinclairii Boott

Alpine, in grassland. Known only from the Snowy R. crossing below Seamans Hut. [Also in N.Z.]

1.* Leaves c. $10 \mathrm{~cm}$ or more in length. The sides of the utricle curved and smooth.

2. Leaves stiff with most closely folded.... $U . \mathrm{sp}$.

Alpine. In grassland at high altitudes. [Also in Vic.]

2.* Leaves stiff or flaccid with most almost flat.

3. Leaves flaccid, usually $<2 \mathrm{~mm}$ in width and very gradually tapering to a long, slender tip U. flaccida S.T. Blake

Widespread but not common. Usually in grass in the shelter of rocks. [Also in Tas. and Vic., and in other subalpine parts of the S. Tlds of N.S.W.]

3.* Leaves rather stiff, usually $>2 \mathrm{~mm}$ in width and tapering rather suddenly near the apex U. compacta $\mathrm{R} . \mathrm{Br}$. Alpine, in grassland at high altitudes. [Also in Vic. and Tas.] 


\section{Carex L.}

1. Spike solitary and terminal on the culm. Utricles with smooth margins.

2. Male part of the spike as long as the female part. Female glumes obtuse C. capillacea Boott

In wet mud in sheltered subalpine areas. [Also in Vic. and extending to N.Z., N. Guinea and to Asia.]

2.* Male part of the spike shorter than the female part. Female glumes rather acute.

3. Lowest female glume bract-like and exceeding the inflorescence.

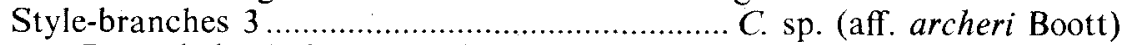

Recorded only from Thredbo R., $1705 \mathrm{~m}$ and Club Lake, $2000 \mathrm{~m}$. [Also from Vic.]

3. ${ }^{*}$ Lowest female glume normal. Style-branches $2 \ldots$ C. cephalotes F. Muell. N.Z.]

Alpine, especially in snowpatch areas. [Also in alpine Vic. and

1. Spikes several to many on the culm, rarely solitary in depauperate plants and then the utricles with setulose margins.

4. Spikes usually elongated and stalked. Terminal spike wholly male or partly female.

5. Style-branches 2 .

6. Terminal spike wholly male ......................... C. gaudichaudiana Kunth

Widespread and common in fen, bog and other wet swampy places. [In all eastern States and extending to N.Z. and Asia.]

6.* Terminal spike part male and part female

C. hypandra F. Muell. ex Benth.

In alpine and occasionally high subalpine areas, in fen, bog and other wet places. [?Endemic, perhaps also in Tas.]

5. Style-branches 3 .

7. Body of the utricle glabrous.

8. Mature spikes usually hidden among the leaves. Utricles indistinctly nerved

C. jackiana Boott Asia.]

Widespread in damp places. [Also in Vic. and extending to

8.* Mature spikes usually on long culms. Utricles finely nerved with a strong marginal nerve C. blakei Nelmes

Subalpine, and occasionally alpine, in wet places. [Found elsewhere in N.S.W. only on high peaks of the A.C.T., but in Vic.]

7.* Body of the utricle puberulent ........................... breviculmis $\mathrm{R}$. Br. Widespread, often in grassland. [In eastern States and extending to Lord Howe Island, N.Z., N. Guinea and Celebes.]

4. ${ }^{*}$ Spikes comparatively short and broad, always partly male and partly female.

9. Spikes densely clustered on a long spike-like panicle. Plants robust. 
10. Culms triquetrous and solid. C. appressa $\mathrm{R}$. Br. Widespread in subalpine areas, often on creek-margins. [Found in all States of Australia and extending to N.Z., N. Caled. and N. Guinea.]

10. Culms terete and hollow C. tereticaulis F. Muell. Found only at Guthega Dam. [Widespread in southern Australia.]

9.* Spikes clustered so as to appear as a head. Plants slender.

11. Utricle reflexed at maturity C. echinata Murray

Widespread in wet places. [Extending to the $N$. Tlds in N.S.W.; also in Vic., N.Z., N. Guinea and in the N. Hemisphere.]

11.* Utricle sometimes spreading but not reflexed.

12. Leaves usually $<2 \mathrm{~mm}$ broad, tapering to a long slender point.

13. Fruiting head usually as broad as long, almost pyramidal..... C. hebes Nelmes

Widespread especially in grassland. [Elsewhere in cooler parts of the S. Tlds in N.S.W. and also in Vic. and S.A.]

13.* Fruiting heads usually longer than broad ......... C. raleighii Nelmes Recorded only from the head of the Tumut R. [Also in Vic.]

12.* Leaves usually $>2 \mathrm{~mm}$ broad for much of their length

Widespread on grassy slopes and creek-banks. [Not C. curta Good. elsewhere in N.S.W. but in Tas., Vic., N. Guinea, S. America and in the $\mathrm{N}$. Hemisphere.]

\section{RESTIONACEAE}

1. Stems slender and flexuose. Upper leaf-sheaths with a spreading or reflexed subulate tip. Fruit 1-locular, a nut Empodisma 1.

1. ${ }^{*}$ Stems robust and erect. Leaf-sheaths not as above. Fruit a 2-3-locular capsule Restio 2.

\section{Empodisma L.A.S. Johnson \& Cutler}

E. minus (Hook. f.) L.A.S. Johnson \& Cutler

Common in bogs and other wet places especially in subalpine areas.

[Widespread in southeastern Australia, and in N.Z.]

2. Restio L. sens. lat.

R. australis $\mathrm{R}, \mathrm{Br}$.

Widespread and common in swamps in subaıpıne areas. [In Tas. and Vic., and in N.S.W. extending to the C. Tlds.]

\section{JUNCACEAE}

1. Leaf-sheaths open or occasionally closed. Seeds numerous Juncus 1 .

1.* Leaf-sheaths closed. Seeds 3 Luzula 2. 


\section{Juncus L.}

Unpublished species have been given letters according to the system used by L.A.S. Johnson in the National Herbarium of New South Wales.

1. Leaves with well-developed blades.

2. Leaves not septate.

3. Leaf-sheaths auricled or lobed at the top.

4. Plants annual. Inflorescences with scattered flowers and overtopping the leafy bracts J. bufonius $\mathrm{L}$.

Common in lower subalpine areas. [In all States; almost cosmopolitan.]

4. * Plants perennial. Inflorescences with clustered flowers; overtopped by leafy bracts. *I. tenuis Willd.

Not common. On well-trodden tracks. [Naturalized in southeastern Australia. Native to N. \& S. America.]

3. Leaf-sheaths tapering into the leaf-margins.

5. Tepals with a pale-greenish central portion............. falcatus E. Meyer Widespread and common. In wet muddy places. [Also in Tas. and Vic., and extending to Japan and western N. America.]

5.* Tepals usually dark-brown.... $J$. antarcticus Hook. f.

Common in alpine and colder subalpine areas, in wet places. [Not found elsewhere in N.S.W. but in Tas., Vic. and N.Z.]

2.* Leaves septate.

6. Inflorescence branched, overtopping the leaves and dark-coloured... *J. articulatus $\mathrm{L}$.

Common especially in more sheltered subalpine areas, in wet places. [Also in all other States. Native to Europe, Asia, N. Africa and N. America.]

6. Inflorescence compact, usually shorter than the leaves; dark- or palecoloured.

7. Inflorescence pale; inner tepals acute and shorter than the outer. Capsule tapering to a beak. J. sandwithii Lourteig

Widespread in wet subalpine areas. [Also in Tas. and Vic., and extending to N. Guinea.]

7.* Inflorescence dark or pale; inner tepals somewhat obtuse and longer than the outer. Capsule rather abruptly contracting into a beak.

8. Inflorescence 1-2-flowered and usually pale J. sp. M6 Widespread in subalpine areas on creek-banks and in pools; occasionally alpine. [Also elsewhere on the S. Tlds of N.S.W. and in Vic.]

8.* Inflorescence several-flowered and usually dark $J$. sp. (aff. scheuchzerioides Gaudich.)

Found only near the junction of Wragges and Pipers creeks. [Apparently endemic.] This material resembles the subantarctic $J$. scheuchzerioides, differing in having shorter tepals, but may represent a hybrid between $J$. sp. M6 and $J$. articulatus. 
1.* Leaves with blades reduced or absent.

9. Pith continuous. Mature capsules reddish or straw-coloured.

10. Mature capsules reddish. Basal sheaths shining J. sp. F In lower sheltered subalpine areas. [Also in Vic., and in N.S.W., extending to the $\mathrm{N}$. Tlds.]

10.* Mature capsules straw-coloured. Basal sheaths not shining..*J. effusus L. In lower sheltered subalpine areas. [A widely naturalized native of the N. Hemisphere and Tropics.]

9.* Pith usually interrupted. Mature capsules straw-coloured (occasionally reddish in $J$. sp.).

11. Main bract shorter than the inflorescence, c. 4-11 cm long $J$. sp. I Scarcely reaching subalpine levels. [Also in Vic. and elsewhere on the S. TIds of N.S.W.]

11. Main bract usually longer than the inflorescence, c. 10-22 cm long $J$. australis Hook. f. In lower subalpine areas, in wet places. [Widespread in N.S.W. Also in Tas., Vic., S.A. and N.Z.]

\section{Luzula L.}

1. Inflorescence of several obviously pedunculate flower-clusters or with only slightly pedunculate clusters.

2. Leaves moderately hairy. Mature capsule usually light creamy brown L. flaccida (Buchen.) E. Edgar

Recorded only from Thredbo R. Gorge, $1554 \mathrm{~m}$. This species is usually in grass or disturbed areas. [In all eastern States.]

2.* Leaves almost glabrous except near the base. Mature capsule bright redbrown .... L. novae-cambriae Gandoger

Common and widespread but apparently more frequent at higher altitudes. Found in grass or among rocks. [Also in Tas. and Vic. and probably elsewhere on the tablelands of N.S.W.] Hybrids between $L$. novae-cambriae and $L$. australasica are found over a wide range of altitudes.

1. Inflorescence with a single ovate flower-cluster or an oblong head with a few sessile lower clusters.

3. Tepals with conspicuous straw-coloured margins.

4. Plants long-rhizomatous. Inflorescence often oblong in outline. Leaf expanding at the apex to a broad blunt tip.............. . australasica Steud.

Widespread and probably common. Usually in bogs. [Elsewhere on the tablelands of N.S.W., extending to Barrington Tops. Also in Tas., Vic., and perhaps N. Guinea.] Hybrids between L. novaecambriae and $L$. australasica are found over a wide range of altitudes.

4. * Plant tufted. Inflorescence ovate in outline. Leaves gradually tapering to a narrow blunt tip.

5. Leaves usually $>3 \mathrm{~mm}$ wide

L. oldfieldii Hook. f. ssp. dura E. Edgar

In high alpine areas on feldmark and exposed eroded areas. [This subspecies is also found in Vic.] The Type subspecies is limited to Tas. 
5.* Leaves usually $<3 \mathrm{~mm}$ wide. L. alpestris Nordenskiöld Limited to alpine and high open subalpine areas usually on moist creek-flats. [Also in Vic.]

3.* Tepals with margins of ten paler but not conspicuous and straw-coloured.

6. Slender tufted plants. Flowering stems usually $>10 \mathrm{~cm}$ high. Leaftips obtuse. L. atrata E. Edgar

Common in alpine areas, rare in colder subalpine areas. In wet places. [Not found elsewhere in N.S.W. but in Tas. and Vic.]

6.* Dwarf mat-forming plants. Flowering stems usually $<5 \mathrm{~cm}$ high. Leaf-tips acute. L. acutifolia Nordenskiöld ssp. nana E. Edgar At high altitudes in wet places. [This subspecies is endemic.] The Type subspecies is found in Tas. and Vic.

\section{LILIACEAE}

1. Fruit a capsule.

2. Flowers in loose racemes or panicles.

3. Perianth not twisted after flowering. Seeds angular Arthropodium 1.

3.* Perianth twisted after flowering or if not twisted then the seeds spherical and papillose Caesia 2.

2.* Flowers solitary and more or less sessile Herpolirion 3.

1.* Fruit a berry.

4. Fruit red or yellow. Flowers greenish Astelia 4.

4.* Fruit blue. Flowers blue Dianella 5.

1. Arthropodium R. Br.

A. milleflorum (Red.) MacBride Found only in sheltered lower subalpine valleys. [In all eastern States and N. Caledonia.]

2. Caesia R. Br.

C. alpina Hook. $\mathrm{f}$.

Rare, subalpine. [Also in Tas. and Vic., and probably elsewhere in the S. Tlds of N.S.W.]

3. Herpolirion Hook. f.

H. novae-zelandiae Hook. f.

Common on creek-flats in subalpine areas; rarely alpine. [Not found elsewhere in N.S.W. but in Tas., Vic. and N.Z.]

\section{Dianella Lam.}

D. tasmanica Hook. f.

Found on south-facing slopes in subalpine areas; rarely alpine. [Also in Tas. and Vic. and in N.S.W. extending to Barrington Tops on the N. Tlds.] 
5. Astelia Banks \& Soland. ex R. Br.

1. Leaves usually $0.5-1.5 \mathrm{~cm}$ wide. Ovary 1 -celled A. alpina $\mathrm{R}$. Br. var. novae-hollandiae Skottsb.

Widespread in bogs and wet places but not as common as $A$. psychrocharis. [Not found elsewhere in N.S.W. but in Vic.] The species extends to Tas., and perhaps N. Guinea.

$1{ }^{*}$ Leaves usually $1.5-2 \mathrm{~cm}$ wide. Ovary 3-celled A. psychrocharis F. Muell. Widespread and common in bogs and wet places. [Endemic.]

\section{ORCHIDACEAE}

1. Leaves absent. Brownish saprophytes with bell-shaped flowers ......Gastrodia 8 .

1.* Leaves present though sometimes absent at flowering time. Plant not as above.

2. Flowers reversed with the labellum uppermost Prasophyllum 3.

2.* Flowers not as above.

3. Plants with 2 or more basal leaves.

4. Leaves 2 Chiloglottis 4 .

4. ${ }^{*}$ Leaves more than 2 .

5. Dorsal sepal and lateral petals forming a hood Pterostylis 7 .

5.* Dorsal sepal not arcuate, the lateral petals usually spreading and clawed Diuris 2.

3.* Plants with a single basal leaf.

6. Perianth almost actinomorphic Thelymitra 1 .

6.* Perianth zygomorphic.

7. Lateral sepals much larger than the dorsal sepal Eriochilus 5.

7.* Lateral sepals similar to the dorsal sepal Caladenia 6.

\section{Thelymitra Forst. \& Forst. f.}

T. venosa $\mathrm{R}$. Br.

In wet sheltered subalpine areas but not common. [Also in Tas., Vic. and S.A., and widespread in southern N.S.W., extending to Barrington Tops, N.Z. and N. Caledonia.]

\section{Diuris Sm.}

Widespread in wet grassland in subalpine areas. [In all eastern States.]

D. pedunculata $\mathrm{R}$. Br.

\section{Prasophyllum $\mathrm{R}$. Br.}

1. Flowers yellow-green to green, often with reddish-brown markings. Petals acute $P$. alpinum $\mathrm{R}$. $\mathrm{Br}$.

Common and widespread, especially in grassland, at all altitudes. [In higher parts of the S. Tlds of N.S.W. and also in Tas. and Vic.] 
1. Flowers with white and purple or mauve markings. Petals obtuse P. suttonii R.S. Rogers \& Rees Common and widespread in moist grassland at all altitudes. [Elsewhere on the S. Tlds of N.S.W. and also in Tas., Vic. and N.Z.]

\section{Chiloglottis R. Br.}

Chiloglottis leaves are frequently observed protruding from Sphagnum but in the absence of flowers it is impossible to identify the species.

1. Flowers pale green. Labellum narrow-ovate C. cornuta Hook. f.

Perhaps rare but as this species grows in Sphagnum and its flowers can be out of sight below the surface it may just be infrequently collected. Probably limited to more sheltered subalpine areas. [Not found elsewhere in N.S.W. but in Tas., Vic., S.A. and N.Z.]

1. ${ }^{*}$ Flowers green or purple-brown. Labellum broad-ovate C. gunnii Lindl.

Grows under similar conditions to $C$. cornuta. [Also in Tas. and Vic., and in N.S.W., extending to Barrington Tops.]

\section{Eriochilus R. Br.}

E. cucullatus (Labill.) Reichb. f.

In moist grassland of lower subalpine areas. Not common. [In all eastern States.]

6. Caladenia $\mathrm{R}$. Br.

C. lyallii Hook. f.

Widespread but not very common. In sheltered places, both alpine and subalpine. [Found elsewhere on the S. Tlds of N.S.W. and also in Tas., Vic. and N.Z.]

\section{Pterostylis $\mathrm{R}$. Br.}

P. alpina $\mathrm{R} . \mathrm{Br}$.

Rare. In wet, sheltered subalpine areas. [Found also in Tas. and Vic., and in N.S.W. extending to the N. Tlds.]

\section{Gastrodia $\mathrm{R}$. Br.}

G. sesamoides $\mathrm{R}, \mathrm{Br}$.

Usually restricted to sheltered subalpine areas. [Found in all States and N.Z., and introduced into S. Africa.]

\section{DICOTYLEDONEAE}

PROTEACEAE

1. Fruit a drupe Persoonia 1 .

1. Fruit a leathery or woody follicle.

2. Follicle with 2 thick woody valves Hakea 3.

2.* Follicle leathery.

3. Perianth inclined to one side. Anthers sessile Grevillea 2.

3. Perianth regular. Anthers on short filaments Orites 4. 


\section{Persoonia $\mathrm{Sm}$.}

Recorded only for Happy Jacks Plain. [Also in Vic. and, in N.S.W., extending to the N. Tlds.]

\section{Grevillea Knight}

1. Leaves to $1 \mathrm{~cm}$ long, with revolute margins.... G. australis $\mathrm{R}, \mathrm{Br}$.

Common at all altitudes, often in heath. [Also in Tas. and Vic., and extending to the C. Tlds in N.S.W.]

1. Leaves 2-7 cm long, with recurved margins G. victoriae F. Muell.

Among rocks in sheltered subalpine valleys but reaching the alpine area at the Sentinel, $1900 \mathrm{~m}$. [Also in Vic. and southeastern N.S.W.]

\section{Hakea Schrad.}

H. microcarpa $\mathrm{R} . \mathrm{Br}$.

In sheltered moist places at low subalpine levels. [Also in Tas. and Vic., and extending to QId.]

\section{Orites $\mathrm{R} . \mathrm{Br}$.}

O. Lancifolia F. Muell.

At alpine and higher, rarely lower, subalpine levels. Usually associated with rocks. [Also in Vic. and elsewhere on the S. Tlds of N.S.W.]

\section{SANTALACEAE \\ Exocarpos Labill.}

Scattered in both alpine and subalpine areas. [Also in Tas., Vic., at high elevations in the A.C.T., and on Barrington Tops, N.S.W.]

\section{POLYGONACEAE}

1. Perianth-segments 6 .

2. Leaves never hastate or sagittate. Flowers hermaphrodite Rumex 1 .

2.* Leaves hastate or sagittate. Plants dioecious Acetosella 2.

\section{Perianth-segments 5 .}

3. Flowers hermaphrodite. Perianth-segments not fleshy in the fruit

Polygonum 3.

3. Flowers unisexual. Perianth-segments often fleshy in the fruit Muehlenbeckia 4.

\section{Rumex L.}

In sheltered disturbed areas. [A widely naturalized native of Europe and Asia.] 
2. *Acetosella (Meisn.) Fourr.

*A. vulgaris Fourr. sens. lat.

In disturbed and especially enriched (by old sheep camps) parts at all altitudes. [Widely naturalized. Native to the N. Hemisphere.] This species has been referred to Rumex, as $R$. acetosella, by M. Gray in Costin et al., Kosciusko Alpine Flora (1979).

\section{Polygonum L.}

* $P$. arenastrum Jord. ex Boreau

On roadsides at lower subalpine levels. [Widely naturalized. Almost cosmopolitan.]

\section{Muehlenbeckia Meisn}

M. axillaris (Hook. f.) Walp.

Rare. In low subalpine areas. [Also in Tas. and Vic., extending to the N. Tlds in N.S.W., and in N.Z.]

\section{PORTULACACEAE}

\section{Montia L.}

1. Leaves usually much more than 4 times as long as broad M. australasica (Hook. f.) Pax \& Hoffm.

Common at all altitudes, often in mud or shallow water, or colonizing bare places. [Widespread in southern Australia and extending to the South and Central W. Slopes and N. Tlds of N.S.W. Also in N.Z.] This species has been placed by some authors in Neopaxia O. Nilss.

1. Leaves usually c. 4 times as long as broad M. fontana L. ssp. fontana

Forming a mat on wet mud. [Also in Tas. and N.Z., and scattered in cold places in both hemispheres.] Two other subspecies are found in warmer and drier parts of southeastern Australia. These can be distinguished by their patterned seed-coat.

\section{CARYOPHYLLACEAE}

1. Stipules minute or absent.

2. Sepals free, at least for the most part.

3. Styles 3-5. Fruit a capsule.

4. Capsule-teeth twice as many as the styles.

5. Styles 3

6. Petals entire or almost so .......................................... Arenaria 5.

6.* Petals deeply bifid or absent ........................................ Stellaria 1.

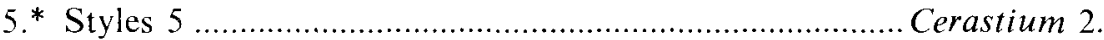

4.* Capsule-teeth equal in number to the styles.

7. Sepals and stamens 4 or if 5 the plant not densely tufted...Sagina 3 .

7.* Sepals and stamens 5. Plant densely tufted .............. Colobanthus 4.

3.* Styles 2. Fruit a small indehiscent nut.............................. Scleranthus 7.

2.* Sepals united, forming a distinct and sometimes inflated tube ........ Silene 8. 
1.* Stipules conspicuous Spergularia 6.

\section{Stellaria L.}

1. Leaves pungent. Stems pubescent S. pungens Brongn.

At lower subalpine levels. [Widespread in southern Australia, common especially on the tablelands of N.S.W.]

1.* Leaves not pungent. Stems glabrous.

2. Perennial. Petals present.

3. Flowers in a loose terminal cyme *S. graminea L.

Rare. At low subalpine levels in moist soil. [A native of Europe and Asia.]

3.* Flowers solitary in the axils

S. angustifolia Hook. Qld.]

Found only on Happy Jacks Plain. [Widespread, and extending to

2.* Annual. Petals lacking

S. multiflora Hook.

Scattered, on shallow or disturbed soils. [Widespread in southern Australia.]

\section{2. *Cerastium $\mathbf{L}$.}

${ }^{*}$ C. fontanum Baumg. ssp. triviale (Murb.) Jalas

Widespread especially in disturbed areas. [A native of Europe widely naturalized in cooler parts of Australia.]

\section{3. *Sagina L.}

Recorded only from moist peaty soil on Happy Jacks Plain. [A Eurasian species widely naturalized in both hemispheres.]

\section{Colobanthus F.G. Bartling}

1. Leaves $>2 \mathrm{~cm}$ long or if less then inconspicuously tapering from the base; their width near the base rarely one-tenth of their length.

2. Sepals obtuse to subacute, shorter than the capsule C. affinis (Hook.) Hook. f.

Alpine. Only at very high altitudes, in grassland or in bare soil. [Also in Tas., Vic. and N.Z.]

2.* Sepals acuminate, mucronate, equal to or longer than the capsule ...... C. apetalus (Labill.) Druce var. apetalus

The only precise locality available is Happy Jacks Plain, $1475 \mathrm{~m}$. [Also in Tas., Vic., S.A. and N.Z. but not found elsewhere in N.S.W.] Another variety has been distinguished in N.Z.

1.* Leaves $<1 \mathrm{~cm}$ long, conspicuously tapering from the base; their width near the base usually c. one-fifth their length.

3. Leaves strongly thickened on the margins. Seeds $0.7-0.8 \mathrm{~mm}$ long.......

Alpine. In bare moist soil in late snow areas. Only at very high altitudes. [Endemic.] 
3. Leaves not strongly thickened on the margins. Seeds $0.5-0.6 \mathrm{~mm}$ long C. nivicola M. Gray

Alpine. Colonizing bare soil. At very high altitudes. [?Endemic. A specimen from Anglers Reach, Lake Eucumbene, appears to belong to this species. This locality is just beyond the northeastern border of the region under review and at an altitude of only $1150 \mathrm{~m}$.]

\section{5. *Arenaria L.}

*A. serpyllifolia $\mathrm{L}$. Europe.]

Occasional, in disturbed areas. [A widely naturalized native of

$$
\text { 6. Spergularia (Pers.) J. \& C. Presl }
$$

*S. rubra (L.) J. \& C. Presl

Common at all altitudes especially in bare disturbed areas. [A widely naturalized native of Europe.]

\section{Scleranthus L.}

1. Flowers paired ....................................... biflorus (Forst. \& Forst. f.) Hook. f.

Widespread and common especially in subalpine areas. [In Tas., Vic.,

QId, N.Z. and S. America, and widespread on the coast and tablelands of N.S.W:]

1. Flowers solitary S. singuliflorus (F. Muell.) Mattf. Alpine and at high subalpine levels, often near rocks. [Also in Vic.]

\section{8. * Silene L.}

*S. vulgaris (Moench) Garcke

Occasional in disturbed places. [Widely naturalized in southern Australia. Native to Europe and W. Asia.]

\section{RANUNCULACEAE}

1. Petals absent. Sepals petaloid. Leaves simple except for 2 inturned basal lobes Caltha 1 .

1.* Petals present. Sepals not petaloid. Leaves not as above Ranunculus 2.

\section{Caltha L.} Vic.]
Alpine and in colder subalpine areas. Common in wet gravel. [Also in

\section{Ranunculus L.}

Many of these species are interfertile and hybrids are not uncommon. The frequency of these hybrids has noticeably decreased since the cessation of grazing in the area.

1. Flowers white.

2. Robust herb with flowers $2-6 \mathrm{~cm}$ diameter $R$. anemoneus $\mathrm{F}$. Muell. In alpine and colder subalpine areas, often below snow-patches. Now spreading in moist grassland. [Endemic.] 
2.* Small stoloniferous herb with flowers $\pm 1 \mathrm{~cm}$ diameter.

R. millanii F. Muell.

Widespread in mud or still, shallow water, as on the floor of contour terraces. [Also in Vic. and elsewhere in cooler parts of the S. Tlds of N.S.W.]

1. Flowers yellow.

3. Leaves simple, entire or 3-dentate or 3-lobed at the apex. Nectary-lobe triangular or absent.

4. Marginal hairs of the leaf-blades appressed. Flowering stems exceeding the leaves............................. $R$. muelleri Benth. var. muelleri Vic.]

In grassland in alpine and colder wet subalpine areas. [Also in

4. ${ }^{*}$ Marginal hairs of the leaf-blades spreading. Flowering stems usually shorter than the leaves.... R. muelleri Benth. var. brevicaulis B.G. Briggs

Alpine. At high altitudes on feldmark. [Endemic.]

3. ${ }^{*}$ Leaves deeply divided or if entire then the nectary-lobe oblong.

5. Plants stoloniferous R. papulentus Melville

In wet subalpine areas. [Also in Vic., and, in N.S.W., extending to the C. Tlds.]

5.* Plants not stoloniferous.

6. Nectary with a distinct lobe.

7. Sepals spreading.

8. Achenes compressed. Stems usually branched and with $2-4$ flowers. Nectary-lobe oblong ....................R. clivicola B.G. Briggs Subalpine. In wet places usually on S.-facing slopes. [Endemic.]

8.* Achenes lenticular. Flowering stems usually simple; if branched then the nectary-lobe truncate.

9. Petals usually $>5$. Leaf-blades divided into linear lobes.. $R$. dissectifolius F. Muell. ex Benth.

Widespread in swampy grassland, mostly at subalpine levels. [Endemic.]

9.* Petals usually 5. Leaf-segments broad.

10. Leaves not pinnate. Petals obovate-cuneate.

11. Nectary-lobe truncate. Flowering stems often branched $R$. lappaceus $\mathrm{Sm}$.

Restricted to sheltered subalpine areas. [Widespread in southeastern Australia and in N.Z.]

11.* Nectary-lobe oblong. Flowering stems usually simple. $R$. graniticola Melville

Widespread in grassland. [Also in Vic. and elsewhere on the S. Tlds of N.S.W.]

10.* Leaves pinnate. Petals elliptical or if obovate-cuneate then the nectary-lobe triangular. 
12. Petals golden-yellow. Flowers usually $>5 \mathrm{~mm}$ in diameter....

R. pimpinellifolius Hook.

Subalpine. In wet places. [Also in Tas., and Vic., and extending to the N. Tlds. in N.S.W.]

12.* Petals pale-yellow. Flowers usually $<5 \mathrm{~mm}$ in diameter $R$. productus B.G. Briggs

In wet subalpine areas, often beside creeks. [Endemic.]

7.* Sepals conspicuously reflexed $R$. scapiger Hook.

In sheltered subalpine areas. [Also in Tas. and Vic. and in N.S.W., extending to the C. Coast.]

6.* Nectary without a distinct lobe.

13. Leaves with narrow terete segments. Petals with multiple nectaries $R$. gunnianus Hook.

In both alpine and subalpine areas. [Not found elsewhere in N.S.W. but also in Tas. and Vic.]

$13 .^{*}$ Leaves \pm orbicular in outline with lobed and dentate segments. Petals with a single nectary R. niphophilus B.G. Briggs Alpine, often beside water; rarely subalpine. [Endemic.]

\section{WINTERACEAE}

Tasmannia R. Br. ex DC.

T. xerophila (Parmentier) M. Gray

Widespread. Often among rocks. [Also in Vic. and in other cool parts of the S. Tlds. of N.S.W.]

\section{BRASSICACEAE}

1. Fruit at least 3 times as long as broad.

2. Fruit not compressed. Flowers yellow.

-3. Fruit with a swollen beak Hirschfeldia 2.

3.* Fruit beakless Barbarea 3.

2.* Fruit compressed. Flowers white or lilac Cardamine 4.

1.* Fruit $<3$ times as long as broad.

4. Fruit laterally compressed (the septum narrow).

5. Ovules numerous in each loculus Capsella 5.

5.* Ovule 1 in each loculus Lepidium 1.

4. ${ }^{*}$ Fruit dorsally compressed (the septum broad).

6. Seeds numerous. Petals bifid Erophila 6. 6.* Seeds few. Petals not bifid Drabastrum 7.

\section{Lepidium $\mathrm{L}$.}

*L. campestre $(\mathrm{L}$.) $\mathrm{R}$. Br.

On roadsides in subalpine areas. [A native of Europe, naturalized in cooler parts of Australia.] 


\section{2. *Hirschfeldia Moench}

${ }^{*}$ H. incana (L.) Lagrèze-Fossat On roadsi
S. Europe.]

\section{Barbarea B. Ehrh.}

B. australis Hook. f.

In wet subalpine areas, often on creek banks. [Also in Tas. and Vic., and elsewhere on the S. Tlds in N.S.W.] Although described in the Flora NovaeZelandiae, the description was based mainly on specimens from Tasmania. Hooker's New Zealand specimens are not considered conspecific.

\section{Cardamine L.}

1. Slender. Flowers small. C. sp.

Widespread and common in heath and grassland. [Also in Tas. and elsewhere on the S. Tlds. of N.S.W.]

1.* Robust. Flowers large. C. sp.

At high, perhaps only alpine, altitudes on margins of lakes and snowpatches. [Also in Vic.]

\section{5. *apsella Medik.}

${ }^{*}$ C. bursa-pastoris (L.) Medik.

Occasional, on roadsides and in disturbed places. [A widely naturalized native of Europe.]

$$
\text { 6. * Erophila DC. }
$$

${ }^{*}$ E. verna (L.) Chevall. ssp. verna

Occasional, in disturbed areas. [A widely naturalized native of Europe.]

\section{Drabastrum (F. Muell.) O.E. Schulz}

D. alpestre (F. Muell.) O.E. Schulz

Recorded only from Happy Jacks Plain. [Also in Vic., and, in N.S.W., extending to the C. Tlds.]

\section{RESEDACEAE}

* Reseda L.

On roadsides at low subalpine altitudes. [A native of Europe, widely naturalized.]

\section{DROSERACEAE}

Drosera L.

1. Leaves all in a basal rosette. Flowers solitary

Widespread in bogs and other wet places. [Also in Tas., Vic. and N.Z. but not found elsewhere in N.S.W.]

$1 .^{*}$ Leaves basal and on the stem. Flowers in a terminal raceme D. peltata $\mathrm{Sm}$. ex Willd.

Subalpine; occasional, on creek banks. [Widespread in eastern Australia.] 


\section{CRASSULACEAE}

\section{Crassula $\mathrm{L}$.}

1. Flowers solitary in the axils. Stems rooting at the nodes.

\section{C. helmsii (T. Kirk) Cockayne}

Subalpine, in wet muddy places. [Widespread in Australia and in Lord Howe Island and N.Z.]

1.* Flowers clustered in the axils. Stems more or less erect

C. sieberana (Schult. \& Schult. f.) Druce

At all altitudes, usually in dry places. [Widespread throughout Australia and in N.Z.]

\section{PITTOSPORACEAE}

Rhytidosporum F. Muell.

R. alpinum McGillivray

In more sheltered subalpine areas. [Scattered on higher parts of the S. Tlds of N.S.W.]

\section{ROSACEAE}

1. Armed shrubs.

2. Fruit an aggregation of drupes Rubus 1 .

2.* Fruit a coloured torus with the achenes enclosed. Rosa 7 .

1.* Unarmed herbs.

3. Petals present, conspicuous and yellow.

4. Carpels with short styles Potentilla 2.

4. ${ }^{*}$ Carpels with hooked persistent styles Geum 3.

3. Petals absent. Flowers small, numerous and green.

5. Flowers in leafy cymes. Leaves not pinnate. Fruit not burr-like.

6. Plant perennial. Inflorescence loose Alchemilla 4.

6. Plant annual. Inflorescence a dense cluster Aphanes 5.

5.* Flowers sessile. Leaves pinnate. Fruit burr-like Acaena 6.

\section{Rubus L.}

R. parvifolius $\mathrm{L}$.

Rare. In lower subalpine areas, among rocks. [Widespread in eastern Australia, extending to eastern Asia.] The Australian material of this species is variable and, contrary to the opinion given by Van Royen [The genus Rubus in New Guinea 4 (1969)], is considered here to be conspecific with that from Japan and China.

\section{2. *Potentilla L.}

*P. recta $\mathrm{L}$.

On roadsides in lower subalpine areas. [Native to Europe and naturalized in cooler parts of Australia.] 


\section{Geum L.}

In lower subalpineareas, especially on creek flats. In Tas. andanum L. extending to the $\mathrm{N}$. Coast, especially on creek flats. In Tas. and Vic. and extending to the N. Coast and Tlds of N.S.W. Also elsewhere in S. temperate regions and in $\mathbf{N}$. temperate regions.]

\section{4. *Alchemilla L.}

*A. xanthochlora Rothm. Europe.]

In moist places at both alpine and subalpine levels. [Native to Central

\section{Aphanes L.}

Occasional, in disturbed areas. [A native of Europe, widely naturalized.]

\section{Acaena L.}

Hybrids between species of Acaena are not uncommon.

1. Flowers in dense globular heads.

2. Leaflets longer than broad, often rather cuneate; much paler and usually pubescent on the under-surface. A. novae-zelandiae Kirk

Scarcely reaching subalpine levels. [Widespread in eastern Australia, extending to Qld. Also in N.Z.]

2.* Leaflets about as long as broad and usually green (though somewhat paler) and glabrous below

A. sp. (aff. anserinifolia (Forst. \& Forst. f.) Druce)

Subalpine and in more sheltered alpine areas, of ten among rocks.

[Also in Tas. but not found elsewhere in N.S.W.]

1. Flowers in long interrupted spikes.

3. Fruit with spines of almost equal length A. agnipila Gandoger In lower subalpine areas. [Widespread in eastern Australia.]

3. Fruit with some spines longer than others A. ovina A. Cunn. Common in lower subalpine areas. [Widespread in eastern Australia.]

\section{7. *Rosa L.}

Occasional in lower subalpine areas. [A native of Europe widely naturalized in cooler parts of Australia.]

\section{MIMOSACEAE}

Acacia Willd.

1. Phyllodes $<5 \mathrm{~cm}$ long.

2. Phyllodes narrow with only the midvein prominent A. siculiformis A. Cunn. ex Benth. In very sheltered subalpine areas on dry hillsides. [Also in Tas. and Vic., and, in N.S.W., extending to the N. Tlds.] 
2.* Phyllodes broad and prominently reticulate. A. alpina F. Muell.

Subalpine. Restricted to sheltered slopes. [Also in Vic. and elsewhere on the S. Tlds of N.S.W.]

1.* Phyllodes 5-15 cm long. A. obliquinervia Tindale Only in sheltered low subalpine areas. [Also in Vic. and extending to the C. Tlds in N.S.W.]

\section{FABACEAE}

1. Stamens free.

2. Pods triangular Daviesia 2.

2.* Pods ovoid or at least not triangular.

3. Leaves usually opposite or whorled. Bracteoles on the pedicel and deciduous Oxylobium 1.

3. Leaves alternate. Bracteoles usually on the calyx and persistent ......

Pultenaea 3.

1.* Stamens variously united.

4. Leaves simple; not unifoliolate Hovea 5.

4.* Leaves of 1-5 leaflets.

5. Leaflets 5 , the lowest 2 resembling leafy stipules Lotus 9.

5.* Leaflets 1-3.

6. All 10 stamens united in one bundle. Leaflets 1 or absent ...Bossiaea 4. 6. 9 stamens united, 1 free. Leaflets usually 3.

7. Legume exceeding the calyx.

8. Legume usually curved or coiled Medicago 6.

8.* Legume straight Melilotus 7.

7.* Legume enclosed in the calyx Trifolium 8.

\section{Oxylobium Andr.}

1. Stipules setaceous. Leaf-veins conspicuously reticulate but with no tubercles between the veinlets O. alpestre F. Muell.

Usually only in sheltered low subalpine areas but occasionally alpine. [In Vic. and elsewhere on the S. Tlds of N.S.W.]

1.* Stipules absent. Leaf-veins less conspicuously reticulate and minutely tuberculate between the veinlets.......................... O. ellipticum (Labill.) R. Br.

Common and widespread on hillsides; scarcely reaching alpine levels. [Widespread in eastern Australia.]

\section{Daviesia $\mathrm{R}$. $\mathrm{Br}$.}

D. mimosoides $\mathrm{R}$. $\mathrm{Br}$.

Recorded from Mt Kosciusko, $1675 \mathrm{~m}$, but if this species reaches subalpine levels at all it must be in very sheltered valleys. [Widespread, from Vic. to Qld.] 


\section{Pultenaea $\mathrm{Sm}$.}

P. fasciculata Benth.

Subalpine. Usually among Poa tussocks. [In Tas. and Vic., and on the tablelands of N.S.W. extending to Barrington Tops.]

\section{Bossiaea Vent.}

B. foliosa A. Cunn.

Widespread on hillsides in subalpine areas. [Extending from Vic. to the C. Tlds of N.S.W.]

\section{Hovea R. Br.}

$H$. sp. (H. purpurea Sweet var. montana Hook. f.)

Widespread in subalpine areas; often on creek flats or around disturbed areas on hillsides; scarcely reaching alpine levels. [Also in Tas. and Vic. and common elsewhere on the S. Tlds of N.S.W.] This taxon has also been known as H. longifolia R. Br. var. montana (Hook. f.) J.H. Willis.

\section{6. *Medicago $\mathrm{L}$.}

1. Plants low-growing or prostrate. The pods not coiled; black at maturity M. Iupulina L.

Planted and naturalized in low sheltered disturbed areas. [A widely naturalized native of the Mediterranean region.]

1.* Plants erect. The pods coiled 2-3 times. ${ }^{*} M$. sativa $\mathrm{L}$.

Planted on roadsides. Probably not naturalized. [Native to the Mediterranean region and Asia.]

\section{7. *Melilotus Medik.}

*M. alba Medik.

In lower subalpine areas, on roadsides. [A widely naturalized native of Europe and W. Asia.]

\section{8. *Trifolium L.}

1. Heads numerous, oblong and densely hairy *T. arvense $\mathrm{L}$.

Occasional, on roadsides. [A widely naturalized native of Europe.]

1.* Heads not as above.

2. Flowers deep pink, the heads surrounded by enlarged stipules

Planted and somewhat naturalized in more sheltered disturbed *T. pratense $\mathrm{L}$. areas. [Native to Europe and W. Asia.]

2.* Flowers white to pale pink, the heads not surrounded by enlarged stipules.

3. Calyx-teeth unequal (the 2 uppermost longer) and separated by narrow sinuses. Stems usually creeping.

Planted at all levels and naturalized in more sheltered disturbed subalpine areas. [A widely naturalized native of Europe and Asia.]

3.* Calyx-teeth subequal and separated by broad sinuses. Stems usually erect or ascending. 
4. Head becoming ovate-oblong; bracts longer than the pedicels ...... *T. ambiguum Bieb. Planted and perhaps naturalized in disturbed areas. [Native to southeastern Europe.]

4.* Head globose; bracts shorter than the pedicels *T. hybridum $\mathrm{L}$.

Planted and naturalized in moisted sheltered areas. [Naturalized in cooler parts of Australia. Native to Europe and W. Asia.]

\section{Lotus L.}

${ }^{*}$ L. pedunculatus Cav.

Planted and naturalized in disturbed sheltered subalpine areas. [A native of Europe, naturalized in cooler parts of Australia.]

\section{GERANIACEAE}

1. Flowers regular Geranium 1.

1.* Flowers irregular, the uppermost sepal spurred Pelargonium 2.

\section{Geranium L.}

1. Flowers mostly in pairs

G. solanderi Carolin var. solanderi

In low subalpine areas. [Widespread in Australia and N.Z., the range of the species.]

1.* Flowers solitary.

2. Flowering stems usually shorter than the basal leaves. Seeds with alveolae absent or minute.

3. Pedicel-hairs antrorse ....................................... antrorsum Carolin In sheltered alpine and subalpine areas. [Also in Vic. and on the S. Tlds of N.S.W. extending to the A.C.T.]

3.* Pedicel-hairs retrorse

G. sessiliflorum Cav. ssp. brevicaule (Hook.) Carolin

In subalpine areas. [Also in Tas., Vic. and elsewhere in the southern part of the S. Tlds of N.S.W.] Other subspecies are found in S. America (the Type ssp.) and N.Z. This taxon seems to differ from $G$. antrorsum only in its pedicel-hairs. Both forms grow together.

2.* Flowering stems usually longer than the basal leaves. Seeds with distinct alveolae.

4. Sepals obtuse. Root napiform............................. obtusisepalum Carolin Scarcely reaching subalpine levels. [Also elsewhere on the S. Tlds of N.S.W.]

4.* Sepals mucronate. Roọt not napiform.

5. Bract \pm midway between the flower and the base of the peduncle. Seeds brown with small alveolae...

G. potentilloides L'Hérit. ex DC. var. potentilloides

Scattered at both alpine and subalpine levels. [Widespread in southern Australia and extending to N.Z. and N. Guinea.] The species extends from the Antarctic islands to Malesia. 
5.* Bract usually towards the base of the peduncle. Seeds black with large alveolae

G. potentilloides L'Hérit. ex DC. var. abditum Carolin Subalpine and occasionally alpine. [Extending from Vic. to the N. Tlds of N.S.W.]

2. Pelargonium L'Hérit. ex Ait.

1. Fertile stamens $4-5$. $P$. helmsii Carolin

In alpine and higher subalpine valleys. [Also in Vic. and perhaps elsewhere on the S. Tlds in N.S.W.]

1.* Fertile stamens 7-8 P. australe Willd.

Subalpine. Perhaps only in the central and northern part of the area. [Widespread in southern Australia, and on Lord Howe Island.]

\section{OXALIDACEAE Oxalis L.}

o. exilis A Cunn.

Only in sheltered subalpine areas, on moist creek flats. [In cooler parts of southeastern Australia, extending to the N. Tlds of N.S.W.] This species has been included in $O$. corniculata $\mathrm{L}$., but differs from that species in having short fruit and single-flowered inflorescences.

\section{LINACEAE}

\section{Linum L.}

L. marginale A. Cunn. ex Planch.

Subalpine, often on damp flats. [Widespread throughout Australia.]

\section{RUTACEAE}

1. Leaves opposite. Petals 4.

2. Petals free Boronia 1.

2. ${ }^{*}$ Petals, at least in the immature flower, cohering in a cylindrical tube Correa 4.

1. Leaves alternate. Petals 5.

3. Calyx conspicuous or at least not hidden. Stigma small. Phebalium 2.

3.* Calyx minute and hidden by hairs. Stigma large Asterolasia 3.

1. Boronia $\mathrm{Sm}$.

In lower subalpine on rocky slopes. [Also in Vic. and extending to northern N.S.W.]

\section{Phebalium Vent.}

1. Flowers terminal ....P. squamulosum Vent. ssp. alpinum (Benth.) P.G. Wilson Occasional on hill slopes at low subalpine levels. [Also in Vic.] The species extends to Qld. Most Kosciusko material falls somewhat between the Victorian ssp. alpinum and ssp. ozothamnoides (F. Muell.) P.G. Wilson of the N.S.W. tablelands. 
1.* Flowers in the upper axils.

2. Leaves narrow-elliptical to linear P. phylicifolium F. Muell.

In sheltered low subalpine areas. [Also in Vic. and elsewhere in the southern part of the S. Tlds of N.S.W.]

2.* Leaves very broadly ovate P. ovatifolium F. Muell. Common and widespread at all altitudes. [Endemic.]

\section{Asterolasia F. Muell.}

A. trymalioides F. Muell.

In lower subalpine areas, often in grassy clearings. [Also in Vic. Limited to the southern part of the S. TIds in N.S.W.]

4. Correa Andr.

C. lawrenciana Hook. var. rosea P.G. Wilson

Barely, perhaps not, reaching subalpine levels. [Limited to the surrounding montane areas of the S. Tlds of N.S.W. and northern Vic.] The species extends from Tas. to A.C.T.

\section{POLYGALACEAE}

Comesperma Labill.

$$
\text { C. retusum Labill. }
$$

In moist situations in lower subalpine areas. [In cooler parts of southern Australia.]

\section{EUPHORBIACEAE}

Poranthera Rudge

$P$. microphylla Brongn. N.Z.]

Widespread in subalpine areas. [Common throughout Australia and in

\section{STACKHOUSIACEAE}

Stackhousia Sm.

S. pulvinaris F. Muell.

In open places at both alpine and colder subalpine levels. [Also in Tas. and Vic.]

\section{MALVACEAE \\ *Malva L.}

*M. nicaeensis All.

Found only at Guthega Dam, $1600 \mathrm{~m}$. [A native of S. Europe, naturalized in cooler parts of Australia.]

\section{HYPERICACEAE \\ Hypericum L.}

H. japonicum Thunb.

Subalpine. Common on creek flats. [Also in Tas. and Vic. and extending to Asia and N.Z.I 


\title{
ELATINACEAE
}

\section{Elatine L.}

\author{
E. gratioloides A. Cunn. \\ N.Z.] \\ Rare. In mud. Subalpine. [Widespread in southeastern Australia and in
}

\section{VIOLACEAE}

1. Plant woody and divaricate. Flowers regular and yellowish ...Hymenanthera 1 .

1.* Plant herbaceous. Flowers irregular, purple or at least not completely yellow..... Viola 2.

\section{Hymenanthera $\mathrm{R}$. Br.}

Widespread at all altitudes. Often among rocks. [Widely distributed in southern Australia.] This species shows considerable variation. The recognition of $H$. angustifolia $\mathrm{R}$. Br. as distinct, either at specific or varietal level, does not seem justified.

\section{Viola L.}

1. Stipules small, entire.

2. Flowers $3 \mathrm{~mm}$ long or less, usually hidden among the leaves V. sieberana Spreng.

Subalpine, often in wet gravel. [Also in Tas. and Vic., and extending at least to Barrington Tops, N.S.W.]

2* Flowers 1-3 cm long, conspicuous .......V. betonicifolia Sm. ssp. betonicifolia Common and widespread. [With a wide distribution in southeastern Australia and extending to southeastern Asia.] Another subspecies is found in N. Guinea.

1. Stipules large and deeply divided *V. arvensis Murr.

Subalpine, in sheltered, disturbed places. [Native to Europe.]

\section{THYMELAEACEAE}

1. Stamens 2. Plants erect or if prostrate the leaves not appearing silky Pimelea 1.

1.* Stamens 4. Plants prostrate, the upper leaves ciliate and appearing silky Kelleria 2.

\section{Pimelea Banks \& Soland. ex Gaertn.}

1. Flowers 2 together. Plants prostrate P. biflora N.A. Wakefield

Subalpine, often on dry eroded banks. [Also in Vic. and, in southern N.S.W., extending to A.C.T.]

1.* Flowers several or many together.

2. Plants prostrate or ascending, the flower-heads sessile among upper leaves ........................................................... . alpina F. Muell. ex Meisn.

Widespread in grassland, often near rocks. [Also in Vic.; not elsewhere in N.S.W.]

2.* Plants erect. 
3. Inflorescences axillary $P$. axiflora F. Muell. ex Meisn. ssp. (var. alpina F. Muell. ex Benth.)

Widespread. [Also in Vic.; not elsewhere in N.S.W.] The species extends to Tas.

3.* Inflorescences terminal.

4. Leaves $1.5-5 \mathrm{~cm}$ long. Bracts $4-8$, broadly ovate, usually pubescent $P$. ligustrina Labill. ssp.

Widespread especially on sheltered slopes. [Also in Tas., Vic. and elsewhere in the southern part of the S. Tlds of N.S.W.] The species is widespread in southeastern Australia.

4.* Leaves 1-2 cm long. Bracts 4, ovate, glabrous ........ P. linifolia Sm. ssp.

Recorded only from Happy Jacks Plain. [Extending to Barrington Tops in northern N.S.W.] The species is widespread in southeastern Australia.

\section{Kelleria Endl.}

K. tasmanica (Hook. f.) Domke

Alpine, often in exposed and windswept places. [Also in Tas.] I have followed Domke, in Biblioth. Bot. 111: 138 (1934), in maintaining the genus Kelleria as distinct from the New World genus Drapetes.

\section{MYRTACEAE}

1. Buds covered by a deciduous operculum Eucalyptus 1 .

1.* Buds not as above.

2. Stamens inconspicuous and shorter than the conspicuous petals.

3. Leaves opposite Baeckea 5 .

3.* Leaves alternate Leptospermum 2.

2.* Stamens conspicuous and longer than the usually inconspicuous petals.

4. Calyx-lobes persisting on the mature fruit Kunzea 3.

4.* Calyx-lobes deciduous before the fruit matures Callistemon 4.

\section{Eucalyptus L'Hérit.}

The lettering system is that of Pryor and Johnson in 'A Classification of the Eucalypts', 1971.

1. A mallee. Buds green .............(MAKKA) E. kybeanensis Maiden \& Cambage

Only in sheltered subalpine areas. [In Vic. and elsewhere in the southern part of the S. Tlds of N.S.W.]

1.* A tree, if shrubby or mallee-like then the buds \pm glaucous.

2. Fruit $7-12 \mathrm{~mm}$ wide.

3. Leaf-veins semilongitudinal (MAKHAC) E. pauciflora Sieber ex Spreng. ssp. niphophila (Maiden \& Blakely) L.A.S. Johnson \& Blaxell

Subalpine, with occasional stunted trees in very sheltered positions at higher levels. Widespread and common. [Also in Vic., and in other subalpine areas in southern N.S.W.] The species is widespread in southeastern Australia. 
3. Leaf-veins at a $30-40^{\circ}$ angle to the midrib

(SPINH) E. glaucescens Maiden \& Blakely

Only in very sheltered subalpine areas. [Also in Vic. and in other parts of the southern S. Tlds of N.S.W.]

2.* Fruit $<7 \mathrm{~mm}$ wide.

4. Bark olive-green to slate-grey. Juvenile leaves not persisting and not perfoliate. (MAKMA) E. stellulata Seiber ex DC.

Only in sheltered low subalpine areas. [Also in Vic., and extending to the N. Tlds of N.S.W.]

4. ${ }^{*}$ Bark whitish. Juvenile leaves usually persisting and perfoliate

. (SPINN) E. perriniana F. Muell. ex Rodway

Only in sheltered low subalpine areas. [Also in Tas., and Vic., and elsewhere on the S. Tlds of N.S.W.]

\section{Leptospermum Forst. \& Forst. f.}

1. Calyx glabrous. Fruit usually $<6 \mathrm{~mm}$ in diameter L. obovatum Sweet

Subalpine. In rocks on the bank and in the bed of the Snowy R. [Also in Vic. and extending to the C. Tlds of N.S.W.]

1. Calyx pubescent. Fruit usually $>6 \mathrm{~mm}$ in diameter L. lanigerum (Ait.) Sm. sens. lat. In sheltered subalpine areas on creek banks and flats. [Also in Tas., Vic. and S.A., and extending to the C. Coast and C. Tlds of N.S.W.]

\section{Kunzea Reichb.}

$K$. muelleri Benth.

At all altitudes, usually on open hill slopes. [Also in Vic. and elsewhere on the S. Tlds of N.S.W.]

\section{Callistemon $\mathrm{R}$. Br.}

1. Leaves $2.5-5 \mathrm{~cm}$ long and $6-8 \mathrm{~mm}$ broad. C. pallidus (Bonpl.) DC.

Recorded only from the Upper Geehi $\mathrm{R}$. and probably not reáching subalpine levels. [Also in Tas. and Vic., and extending to Qld.]

1. ${ }^{*}$ Leaves $1.5-2.5 \mathrm{~cm}$ long and $2 \mathrm{~mm}$ broad C. sieberi $\mathrm{DC}$. Qld.]

In wet sheltered parts of subalpine areas. [Also in Vic., extending to

\section{Baeckea L.}

1. Leaves 4-6 (-10) $\mathrm{mm}$ long, the upper surface almost flat, the lower keeled B. utilis F. Muell. ex Miq.

At all altitudes, of ten along streams. [Also in Vic. and reaching the $N$. Tlds in N.S.W.]

1. Leaves 2-4 mm long, the upper surface concave or channelled, the lower convex but not keeled B. gunniana Schauer

At all altitudes, in bogs and often along streams. [Also in Tas. and Vic. and extending to the N. Tlds in N.S.W.] 
ONAGRACEAE

1. Hypanthium not or scarcely extending above the ovary. Flowers small, usually $<1 \mathrm{~cm}$ in diameter Epilobium 1.

1. Hypanthium extended above the ovary. Flowers large, of ten $3 \mathrm{~cm}$ diameter Oenothera 2.

\section{Epilobium L.}

1. Plant covered with long, fine, spreading hairs E. hirtigerum A. Cunn.

Scarcely reaching subalpine levels. [Widespread in southeastern Australia, extending to Indonesia, N.Z. and S. America.]

1.* Pubescence not as above.

2. Flowers white. Plant low-growing and matted ........ E. tasmanicum Hausskn.

In alpine and high subalpine areas in wet places, often colonizing disturbed areas. [Also in Tas. and N.Z.]

2.* Flowers pale to dark, often purplish, pink or if white then the plant tallgrowing.

3. Low-growing. Fruit enlarged in the upper part. Seeds lacking a coma E. curtisiae Raven

In more sheltered subalpine areas in wet places. [Elsewhere in southern subalpine N.S.W. and in Tas. and Vic.]

3.* Tall-growing. Fruit not as above. Seeds comose.

4. Plant minutely hoary

... E. billarderianum Sér. ssp. cinereum (A. Rich.) Raven \& Engelhorn

In more sheltered dry, often disturbed, subalpine areas. [Widespread in southeastern Australia and in Lord Howe Island and N.Z.] The species has a similar distribution.

4.* Plant not hoary.

5. Seeds with a pale rim ................................E. gunnianum Hausskn.

Widespread in moist places. [Also in Tas. and Vic. and extending in N.S.W. to the N. Tlds. Rare in N.Z.]

5.* Seeds without a rim.

6. Stems with hairs only along lines from the base of the petiole. Seeds marked with parallel lines of papillae ......* E. ciliatum Raf.

In lower subalpine areas in damp or wet places. [Widely naturalized in eastern Australia. Native to N. America.]

6. ${ }^{*}$ Stems usually pubescent all around. Seeds finely papillose or almost smooth; not marked as above.

7. Flowers with a ring of hairs in the base of the tube. Seeds finely papillose.

.. E. billardierianum Sér. ssp. hydrophilum Raven \& Engelhorn

In sheltered subalpine areas, in wet places. [Also in Vic. and extending to Qld.] The species extends to Lord Howe Island and N.Z.

7.* Flowers with the inner surface of the tube glabrous. Seeds almost smooth E. sarmentaceum Hausskn.

Alpine and in higher subalpine areas, often among rocks. [Also in Tas. and Vic.] 


\section{2. * Oenothera L.}

* O. erythrosepala Borb.

On roadsides at low subalpine levels. [A native of Europe naturalized in cooler parts of Australia.]

\section{HALORAGACEAE}

1. Fruiting carpels cohering at maturity, the septa almost lacking. Plants usually terrestrial Gonocarpus 1.

1. Fruiting carpels breaking into separate 1 -seeded mericarps. Plants aquatic or in mud Myriophyllum 2.

\section{Gonocarpus Thunb.}

1. Leaves ovate, dentate. Stems antrorsely scabrid. Mature fruit $\pm 1 \mathrm{~mm}$ wide. G. montanus (Hook. f.) Orchard

Widespread, often in rocky places. [Also in Tas., Vic. and N.Z., and elsewhere on the higher S. Tlds of N.S.W.]

1. Leaves broadly ovate to suborbicular, crenulate. Stems glabrous. Mature fruit $\pm 0.5 \mathrm{~mm}$ wide G. micranthus Thunb. ssp. micranthus

Widespread in wet places. [Common in eastern Australia. Also in N.Z., N. Guinea, Malesia and Asia, the distribution of the species.]

\section{Myriophyllum L.}

1. Leaves all linear, opposite M. pedunculatum Hook. f.

At all altitudes, in mud, often on the floor of the contour terraces. [Widespread in southern Australia and extending to N.Z. and N. Guinea.]

1.* Lower leaves divided, all whorled. M. propinquum A. Cunn. sens. lat. N.Z.]

At low subalpine levels, in water. [Widespread in Australia and in

\section{ARALIACEAE}

Polyscias Forst. \& Forst. f.

P. sambucifolia (Sieber ex DC.) Harms

In sheltered low subalpine areas. [Also in Vic. and extending to the $\mathrm{N}$. Coast and Tlds of N.S.W.]

\section{APIACEAE}

1. Leaves transversely septate, simple and linear or pinnate or bipinnate with linear segments. Aciphylla 8.

$1 .^{*}$ Leaves not as above.

2. Fruits laterally compressed.

3. Stipules present Hydrocotyle 1.

3.* Stipules absent Trachymene 2.

2.* Fruits scarcely or dorsally compressed.

4. Leaves undivided. 
5. Leaves narrowly cuneate and distally toothed.....

Oschatzia 3.

5.* Leaves petiolate with a broad blade.

6. Leaves glabrous.

7. Umbel pedunculate. Diplaspis 4.

7.* Umbel sessile or almost so Schizeilema 5.

6. Leaves hispid Dichosciadium 6.

4. ${ }^{*}$ Leaves pinnately divided.

8. Umbel simple Oreomyrrhis 7 .

8.* Umbel compound Gingidia 9.

\section{Hydrocotyle L.}

1. Leaves crenately lobed H. algida N.A. Wakefield

Common in subalpine areas especially on creek flats. [Also in Vic. and elsewhere on the N.S.W. Tlds.]

1. Leaves deeply divided H. sp.

Recorded only from wet places on Happy Jacks Plain. [Also elsewhere on the S. Tlds of N.S.W.]

\section{Trachymene Rudge}

1. Leaf-blades much-dissected T. sp.

Occasionally reaching subalpine levels in the northern part of the area. [Also in Tas. and Vic., and in N.S.W. extending to the N. Coast]. This species has been included in the Western Australian species T. anisocarpa by some authors but it differs from that species in a number of characters.

1.* Leaf-blades entire or shallowly lobed .................. T. humilis (Hook. f.) Benth.

Only at low altitudes, perhaps reaching subalpine levels only on Happy Jacks Plain. [In Tas., Vic. and elsewhere on the S. Tlds of N.S.W.]

\section{Oschatzia Walp.}

O. cuneifolia (F. Muell.) Drude

Widespread in wet places, of ten in Sphagnum. [Limited to this area in N.S.W. but also in Vic.]

\section{Diplaspis Hook. f.}

D. hydrocotyle Hook. f.

Almost entirely limited to alpine areas. In bogs and other wet places. [Also in Tas. and Vic.]

\section{Schizeilema Domin}

S. fragoseum (F. Muell.) Domin

Especially in high alpine areas, often in seepage around the bases of rocks but recently found spreading over moist grassland. [Also in Vic.]

\section{Dichosciadium Domin}

D. ranunculaceum (F. Muell.) Domin. var. ranunculaceum

Only at high alpine levels in late snow areas. [Endemic.] Tasmanian material has been distinguished as a variety. 


\section{Oreomyrrhis Endl.}

1. Plants in low-growing tufts; leaf-segments obtuse O. pulvinifica F. Muell. In wet places especially in high alpine areas. [Also in Vic.]

1. Plants rarely in low-growing tufts and if so then the leaf-segments acute.

2. Leaves densely silvery pubescent O. argentea Hook. f.

Widespread in lower subalpine grassland. [Also in Tas., Vic. and elsewhere on the S. Tlds of N.S.W.]

2.* Leaves not densely silvery pubescent.

3. Plants with branched leafy stems. O. brevipes Mathias \& Constance

In alpine and higher subalpine areas, usually among rocks. [Also in Vic.] Hybridization occurs between this species and $O$. eriopoda, and intermediates are common at all altitudes in the Kosciusko area.

3.* Leaves all in a basal rosette.

4. Leaves almost glabrous except on the margins. Ultimate leafsegments acute. O. ciliata Hook. f.

Widespread, especially at subalpine levels. [In Tas. and Vic., and, in N.S.W., extending to Barrington Tops.]

4. ${ }^{*}$ Leaves densely to sparsely hirsute. Ultimate leaf-segments obtuse O. eriopoda (DC.) Hook. f.

Only in lower subalpine areas. [In Tas. and Vic. and widespread through the tablelands and coastal ranges of N.S.W.] Specimens showing hybridization between this species and the highaltitude $O$. brevipes are common.

\section{Aciphylla Forst. \& Forst. f.}

1. Leaves much-divided into numerous, stiff, pungent segments A. glacialis (F. Muell.) Benth.

Common and widespread on open hilisides; more at alpine than subalpine levels. [Also in Vic.]

1.* Leaves entire, linear, septate and soft A. simplicifolia (F. Muell.) Benth.

Common and widespread, perhaps more at subalpine levels. [Also in Vic. and elsewhere on the S. Tids of N.S.W.]

\section{Gingidia Dawson}

1. Leaves with short broad leaf-divisions G. algens (F. Muell.) Dawson

Widespread in damp places especially at subalpine levels. [Endemic.]

1.* Leaves with long, slender leaf-divisions........G. harveyana (F. Muell.) Dawson

Only in lower sheltered subalpine areas. [Also in Vic. and extending to the N. Tlds of N.S.W.]

\section{EPACRIDACEAE}

1. Style inserted in a depression between the carpels.

2. Leaves with broad sheathing bases Richea 1.

2.* Leaves articulate at the base Epacris 2. 
1. Style terminal.

3. Fruit a drupe.

4. Corolla-lobes pubescent on the inner surface. Leaves (in the species in the area) recurved in cross-section and often with some hairs on the lower surface Leucopogon 3.

4.* Corolla-lobes glabrous, occasionally with papillae, rarely with a few hairs, on the inner surface. Leaves (in the species in the area) flat and glabrous. Lissanthe 4.

3.* Fruit drupe-like, the stone separating into 5 parts Pentachondra 5.

\section{Richea R. Br.}

Widespread in wet places, especially boggy valleys. [Also in Vic. and at high elevations in the A.C.T., but not found elsewhere in N.S.W.]

\section{Epacris Cav.}

1. Corolla-tube as long or longer than the sepals E. paludosa $\mathrm{R}$. Br.

Widespread and common in wet places, especially bogs. [Also in Tas. and Vic., and extending to the N. Tlds of N.S.W.]

1.* Corolla-tube very short.

2. Flowers axillary and extending along the branches....E. microphylla $\mathrm{R}$. Br.

Widespread and common at all altitudes, and tolerant of very exposed conditions. [In Tas. and Vic., and extending to S.A. and Qld.]

2.* Flowers axillary in the upper axils, forming head-like clusters.

3. Bracts pale and narrow.

4. Leaves with a blunt or very shortly pointed incurved tip.

5. Plant low-growing, with leaves often twice as long as broad and most leaves imbricate

E. petrophila Hook. f.

Alpine and in cold subalpine areas, in swampy valleys. [Also in Tas. and Vic.]

5.* Plant usually erect, with leaves usually as broad as long and of ten scattered along the stems. E. sp.

Subalpine, in moist places. [Also in Vic. and elsewhere on higher parts of the S. Tlds of N.S.W.]

4. ${ }^{*}$ Leaves with a distinct, almost straight, often pungent, point E. breviflora Stapf

In swampy places in the northern part of the region, at lower subalpine levels. [Also in Vic., and extending to southern Qld.]

3.* Bracts reddish-brown and broad E. glacialis (F. Muell.) M. Gray In alpine and high subalpine areas, in wet places. [Also in Vic.] 
3. Leucopogon $\mathrm{R}$. Br.

1. Leaves oblong, the margins recurved L. hookeri Sond.

In subalpine and lower alpine areas, often in grassland. [In Tas. and Vic., and extending to the N. Tlds of N.S.W., probably in southern Qld; perhaps also in N.Z.] The N.Z. plant Leucopogon colensoi Hook. f. (at present known there as Cyathodes colensoi) is very similar, and may prove to be conspecific.

1. Leaves ovate, flat L. maccraei F. Muell.

Perhaps restricted to the Munyang (Whites) R. Valley. [Also in Vic., but in N.S.W. found elsewhere only near the lower (montane) Munyang R.]

\section{Lissanthe $\mathrm{R} . \mathrm{Br}$.}

L. montana $\mathrm{R} . \mathrm{Br}$.

Common among rocks in alpine and exposed high subalpine areas. [Also in Tas. and Vic.] This species has been placed in Leucopogon, as $L$. montanus (R. Br.) J.H. Willis, by some authors.

\section{Pentachondra R. Br.}

P. pumila (Forst. \& Forst. f.) R. Br.

Alpine and in more exposed subalpine areas, often on rocks. [Also in Tas., Vic. and N.Z.]

\section{LOGANIACEAE}

Mitrasacme Labill.

M. serpyllifolia $\mathrm{R}$. Br.

Recorded only from Happy Jacks Plain. [Also in Tas. and Vic., and reaching the N. Tlds of N.S.W.]

\section{GENTIANACEAE \\ Gentianella Moench}

G. diemensis (Griseb.) J.H. Willis

Widespread. Often in moist grassland. [Also in Tas., Vic. and S.A., and extending to Barrington Tops in N.S.W.] The variation in this species requires further study.

\section{CONVOLVULACEAE}

Dichondra Forst. \& Forst. f.

D. micrantha Urban

Only in lower subalpine areas in the northern part of the area. [Found from the Coast to W. Plains in N.S.W. and widespread in both hemispheres.] 


\section{BORAGINACEAF}

1. Corolla regular. Flowers small.

2. Fruitlets obliquely attached to a conical receptacle Cynoglossum 1.

2.* Fruitlets attached basally to an almost flat receptacle Myosotis 2.

1.* Corolla zygomorphic. Flowers large Echium 3.

1. Cynoglossum L.

C. australe $\mathrm{R} . \mathrm{Br}$.

A roadside occurrence at Diggers Creek Lake. [Throughout temperate Australia.]

\section{Myosotis L.}

1. Calyx-lobes broadly triangular, \pm as long as the tube, and usually bearing hooked hairs M. australis $\mathrm{R}$. Br.

Subalpine, rarely alpine. [Widespread in southern Australia, extending to the N. Tlds of N.S.W. and N.Z.]

1. Calyx-lobes narrow, c. twice as long as the tube and without hooked hairs *M. discolor Pers.

In subalpine and perhaps alpine areas. [A native of Europe naturalized in cooler parts of Australia.]

\section{3. ${ }^{*}$ Echium L.}

${ }^{*} E$. vulgare $\mathrm{L}$.

On roadsides in lower subalpine areas. [A native of Europe widely naturalized in Australia.]

\section{LAMIACEAE}

1. Calyx 5-toothed; not 2-lipped Westringia 1.

1. Calyx deeply divided into 2 lips.

2. Lips of the calyx entire. Stamens 4 Prostanthera 2.

2.* Lips of the calyx toothed. Stamens 2 Salvia 3.

1. Westringia $\mathrm{Sm}$.

scattered occurrence in subalpine areas, often near Snow Gums. [Endemic in the southern part of the S. Tlds of N.S.W.]

\section{Prostanthera Labill.}

P. cuneata Benth.

Common and widespread in heath and woodland. [Also in Tas. and Vic., and on high peaks in the A.C.T., but not elsewhere in N.S.W.]

\section{Salvia L.}

*S. verbenaca $\mathrm{L}$.

Recorded from Guthega Dam. [A native of Europe, widely naturalized in southeastern Australia.] 


\section{SCROPHULARIACEAE}

1. Corolla minute. Plants aquatic or in mud.

2. Stigma dilated into a flattened, curved lamina. Glossostigma 4.

2.* Stigma capitate Limosella 5 .

1.* Corolla $>2 \mathrm{~mm}$ in length or diameter. Plants of wet or dry habitats.

3. Upper lip, or 2 upper lobes, of corolla covering the lateral lobes in the bud.

4. Leaves alternate on the flowering stems. Corolla with spreading lobes Verbascum 1.

4.* Leaves opposite. Corolla tubular.

5. Calyx-teeth short. Stamens 4 Mimulus 2.

5.* Calyx deeply divided. Stamens 2 Gratiola 3.

3.* Upper lip, or 2 upper lobes, of corolla covered by one or both of the lateral lobes in the bud.

6. Corolla almost regular. Stamens 2 .

7. Leaves crowded, coriaceous, small and entire Chionohebe 8.

7.* Leaves not as above.

8. Soft and usually lax herbs. Capsules usually obcordate and opening at first loculicidally Veronica 6.

8.* Erect suffruticose herbs. Capsules compressed-ovoid and opening at first septicidally Parahebe 7.

6.* Corolla 2-lipped. Stamens 4 Euphrasia 9.

\section{1. *Verbascum L.}

1. Pubescence densely white-woolly *V. thapsus L.

On roadsides at low subalpine altitudes. [A native of Europe naturalized in cooler areas in Australia.]

1.* Pubescence sparse, glandular..... *V. virgatum Stokes?

In disturbed lower subalpine areas. [A native of Europe, widely naturalized.]

\section{Mimulus L.}

${ }^{*} M$. moschatus Douglas ex Lindl.

Occasional, at low altitudes, on wet creek banks. [A native of $\mathrm{N}$. America naturalized in cooler areas.]

\section{Gratiola L.}

G. nana Benth.

Only in swampy areas at subalpine altitudes. [Also in Tas., Vic. and N.Z. Found elsewhere in N.S.W. only at high elevations in the A.C.T.] 
4. Glossostigma Wight \& Arn. ex Arn.

G. sp. (G. spathulatum Arn. nom. illeg.)

Recorded only from Diggers Creek Reservoir, in water. [Widely distributed in Australia. Also in Asia and Africa.]

\section{Limosella $\mathrm{L}$}

L. australis $\mathrm{R}$. Br.

Recorded only from Diggers Creek Reservoir, in mud. [Widespread in eastern Australia. Also in N.Z., Africa and America.]

\section{Veronica L.}

1. Leaves ovate to oblong, obtuse; toothed or entire.

2. Leaves distinctly toothed. Corolla shorter than the calyx ......* ${ }^{*}$. arvensis $\mathrm{L}$. Widespread in lower subalpine areas, rarely alpine. [A native of Europe and W. Asia, widely naturalized.]

$2{ }^{*}$ Leaves entire or almost so. Corolla longer than the calyx V. serpyllifolia $\mathbf{L}$.

Widespread, especially in wet subalpine areas and sheltered alpine valleys. [Also in Tas. and Vic., and in N.S.W. reaching the C. Coast (though perhaps introduced there). Also in the N. Hemisphere.]

1. Leaves narrowly elliptical to lanceolate, of ten toothed V. gracilis $\mathrm{R}$. Br.

In more sheltered subalpine areas, in moist grassland. [Also in Tas., Vic. and S.A., and reaching the N. TIds of N.S.W.]

\section{Parahebe Oliv.}

1. Leaves entire or toothed.

2. Leaves stem-clasping, entire or with a few teeth. Flowers mauve to purple .P. perfoliata (R. Br.) B.G. Briggs \& Ehrend.

Recorded only from Happy Jacks Plain. [Also in Vic. and extending to the C. Tlds and C.W. Slopes of N.S.W.]

2.* Leaves not stem-clasping, serrate. Flowers white to pale-mauve P. derwentiana (Andr.) B.G. Briggs \& Ehrend. ssp. (Veronica maideniana Gandoger)

Subalpine. Common on sheltered hillsides. [Also in Vic. and the S. Tlds of N.S.W. extending to the A.C.T.] The species is widespread in eastern Australia.

1. Leaves deeply dissected. P. sp. (Veronica nivea Lindl.)

Subalpine. Uncommon and usually along road-verges. [Also in Tas. and Vic. but not found elsewhere in N.S.W.]

\section{Chionohebe B.G. Briggs \& Ehrend.}

C. densifolia (F. Muell.) B.G. Briggs \& Ehrend. N.Z.]

Only in very high exposed alpine areas especially in feldmark. [Also in 


\section{Euphrasia L.}

1. Plants annual.

2. Flowers white with dark stripes. Plants usually less than $10 \mathrm{~cm}$ tall $\ldots$. E. alsa F. Muell.

Alpine and in colder subalpine areas, often in bare patches in grassland. [Endemic.]

2. Flowers mauve. Plants often more than $10 \mathrm{~cm}$ tall E. sp. (E. scabra R. Br. var. caudata J.H. Willis)

Occasional in sheltered, grassy subalpine areas. Rare and dwarfed at alpine levels. [Also in Vic. and elsewhere on the S. Tlds of N.S.W.]

1.* Plants perennial.

3. Corolla with a yellow blotch on the lower lip. Calyx glandular-pubescent.

4. Plant usually more than $15 \mathrm{~cm}$ tall E. collina $\mathrm{R}$. Br. ssp.

Common and widespread especially in grassland in alpine and higher subalpine areas. [Elsewhere on the southern S. Tlds of N.S.W.] In intermediate habitats this subspecies intergrades with the subspecies (E. glacialis Wettst.) found in wet places.

4.* Plant usually less than $15 \mathrm{~cm}$ tall.

5. Flowers white E. collina R. Br. ssp.

(E. glacialis Wettst.)

Alpine, occasionally in colder subalpine areas. On the margins of pools and in other wet places. [Endemic.] This subspecies intergrades with that found in drier grassland.

5.* Flowers mauve-pink

E. collina R. Br. ssp.

At high altitudes on feldmark. [Endemic.]

3.* Corolla lacking a yellow blotch on the lower lip. Calyx usually glabrous with dense or sparse subsessile glands

E. collina $\mathrm{R}$. Br. ssp.

(E. paludosa R. Br.)

Common in subalpine grassland and woodland. [Also in S.A. and Vic., and extending to Qld.] The species E. collina is widespread in southern Australia.

\section{LENTIBULARIACEAE}

Utricularia L.

U. monanthos Hook. f.

Subalpine. Occasional in water or mud. [Also in Tas., elsewhere on the

S. TIds of N.S.W. and in N.Z.]

\section{PLANTAGINACEAE}

Plantago L.

1. Scapes with regular longitudinal ridges *P. lanceolata $\mathrm{L}$.

Subalpine. Occasional on roadsides. [Widely naturalized. Native to Europe and Asia.]

1. Scapes not conspicuously ridged. 
2. Taproot not developed.

3. Spikes with 1-8 flowers.

4. Leaves to $5 \mathrm{~mm}$ broad. Rosettes small, forming a turf $P$. glacialis Briggs, Carolin \& Pulley Alpine. In wet areas below snow-patches. [Also in Vic.]

4. ${ }^{*}$ Leaves $>5 \mathrm{~mm}$ broad. Rosettes not forming a turf P. muelleri Pilger In alpine and higher subalpine areas, often on creek banks. [Also at high altitudes in the A.C.T.]

3. ${ }^{*}$ Spikes mostly with $>10$ flowers.

5. Leaves $3(-5)$-nerved, the lateral nerves much less conspicuous on the upper surface than the midvein $P$. alpestris Briggs, Carolin \& Pulley Vic.]

In alpine and higher subalpine areas, in wet places. [Also in

5.* Leaves (3-) 5 (-9) -nerved, the nerves mostly all conspicuous on the upper surface .......................... e euryphylla Briggs, Carolin \& Pulley

Alpine and subalpine, often in grassland. [Also in Vic. and high parts of the A.C.T. but not found elsewhere in N.S.W.]

2.* Taproot developed.

6. Sepals usually $2.1-2.5 \mathrm{~mm}$ long, with a glabrous carina

$P$. antarctica Decaisne

Low subalpine, especially in the northern part of the area, in grasstand. [Also in Tas. and Vic., and elsewhere in the S. Tlds of N.S.W., extending to the A.C.T.]

6. ${ }^{*}$ Sepals usually $2.8-3.5 \mathrm{~mm}$ long with a pilose carina .......... . varia $\mathrm{R}$. Br. Rare; recorded only from $\mathrm{Mt}$ Jagungal. [Widespread in the southern half of N.S.W. Also in Tas., Vic. and S.A.]

\section{RUBIACEAE}

1. Leaves opposite, with the stipules inconspicuous.

2. Flowers bisexual. Calyx 2-lobed or obsolete. Nertera 1.

2.* Flowers usually unisexual. Calyx 4-5 lobed at least in the female flower Coprosma 2.

1.* Leaves whorled, with the leaf-like stipules included in the whorl... Asperula 3.

\section{Nertera Banks ex Gaertn.}

N. granadensis (Mutis) Druce

In both alpine and subalpine areas especially on wet creek flats. [Also in Tas., Vic., N.Z., N. Guinea and S. America. Extending to the N. Tlds of N.S.W.] Some authors distinguish the Australasian material from the S. American, as N. depressa Banks \& Soland. ex Gaertn. 
2. Coprosma Forst. \& Forst. f.

1. Leaves narrowly obovate to almost linear C. nivalis W.R.B. Oliver

Found in dry soil in grassland only in the northern part of the area. [Of restricted distribution on the S. Tlds of N.S.W. and in Vic.]

1.* Leaves not as above.

2. Leaves ovate above a conspicuous attenuate base

C. sp. (C. pumila auct. non Hook. f.)

Found forming a dense cover on rocks on the banks of streams in alpine and high subalpine areas. [Also in Tas., Vic., N.Z. and Macquarie Island.] This species, well known as $C$. pumila, was first collected in the area in 1971, on the bank of the Snowy R. at $1630 \mathrm{~m}$ alt. It has since been found at one alpine locality in a similar habitat. All references in literature to the occurrence of $C$. pumila at Kosciusko apply to the following species.

2. Leaves elliptical or somewhat broader above or below the centre. The base not attenuate C. $\mathrm{sp}$.

Alpine, on well drained rocky hillsides and on scree at high altitudes. [Endemic.] This species was, until recently, referred incorrectly to $C$. pumila, i.e. C. pumila auct. non Hook. f.

\section{Asperula L.}

1. Leaves acute to acuminate and mucronate.

2. Leaf-apex acuminate, the mucro straight. A. scoparia Hook. f.

At lower subalpine levels. [In Tas., Vic. and S.A., and extending to the C. Tlds of N.S.W.]

2.* Leaf-apex acute to shortly acuminate, the mucro recurved A. conferta Hook. f.

Occasional, especially on open hillsides. Subalpine. [Widespread in temperate eastern Australia.]

1.* Leaves obtuse or shortly acute, not mucronate.

3. Upper leaf-surface glabrous A. gunnii Hook. f.

Common and widespread. [Also in Tas. and Vic., and reaching the N. Tlds of N.S.W.]

3.* Upper leaf-surface hispid A. pusilla Hook. f.

Subalpine and occasionally alpine, of ten among rocks. [Also in Tas., Vic. and elsewhere on the S. Tlds of N.S.W.]

\section{CAMPANULACEAE \\ Wahlenbergia Schrad.} persist.

Most species hybridize readily in disturbed habitats but hybrids rarely

1. Flowers with a very short tube, appearing rotate W. multicaulis Benth.

Subalpine, usually under trees; perhaps reaching subalpine levels only on the Happy Jacks Plain. [Widespread in eastern mainland Australia.]

1.* Flowers with a conspicuous tube. 
2. Leaves $\pm 1 \mathrm{~cm}$ long, crowded along the base of the stem

W. densifolia Lothian

Only at lower subalpine levels, on moist flats. [Also in Vic. and scattered on the S. Tlds of N.S.W.]

2.* Leaves not as above.

3. Calyx-lobes conspicuously longer than the tube and usually hairy.... W. stricta Sweet

Reaching subalpine levels only on hillsides among Snow Gums at Happy Jacks Plain. [Widespread throughout Australia and in N.Z.]

3.* Calyx-lobes not conspicuously longer than the tube, glabrous.

4. Flowers dark blue to purple. Leaves conspicuously crisped W. gloriosa Lothian

Rare, in both alpine and subalpine areas. In rocky places. [Also in Vic. and elsewhere in the southern part of the S. Tlds of N.S.W.]

4. Flowers usually mid-blue to white, occasionally dark blue or mauve. Leaves not or sparsely crisped. W. ceracea Lothian Widespread and common in moist places especially on swampy flats. [Also in Tas. and Vic. Extending to the N. Tlds of N.S.W.]

\section{LOBELIACEAE}

\section{Pratia Gaudich.}

1. Leaves dentate. Flowers blue, rarely lavender or white. Seeds smooth .... $P$. pedunculata (R. Br.) Benth. sens, lat. Common in subalpine grassland. [In southeastern Australia, reaching Gloucester Tops in northern N.S.W.] The names $P$. puberula Benth. and $P$. pedunculata (R. Br.) Benth. have been applied to this species. The material is variable and $P$. puberula cannot be segregated from the more widespread species. This complex needs further study.

1.* Leaves entire. Flower pale-pink to white. Seed-surface with a distinct pattern ...................................... . sp. (aff, surrepens (Hook. f.) F.E. Wimm.)

At all altitudes in mud, especially on the floor of contour terraces. [Also in Vic. and elsewhere in the southern part of the S. Tlds of N.S.W.] The Type of $P$. surrepens is Tasmanian. J.D. Hooker describes a plant with small blue flowers. This complex needs further study.

\section{GOODENIACEAE}

1. Flowers yellow. Seeds flat.

2. Ovary superior Velleia 1.

2.* Ovary inferior Goodenia 2.

1.* Flowers not yellow. Seeds not flattened Scaevola 3. 
1. Velleia $\mathrm{Sm}$.

1. Peduncles shorter than the leaves. Flowers pale to clear yellow V. montana Hook. f.

In rather moist subalpine areas. [Also in Tas. and Vic. and extending to the N. Tlds of N.S.W.]

1.* Peduncles more than twice as long as the leaves. Flowers bright yellow to orange V. paradoxa $\mathrm{R}$. Br.

Recorded only from Happy Jacks Plain. [Widespread throughout temperate Australia.]

\section{Goodenia Sm.}

$G$. hederacea Sm. var. alpestris Krause

Usually subalpine, on dry hillsides, especially at lower levels; rarely extending above the treeline. [Also in Vic. and elsewhere in the southern part of the S. Tlds of N.S.W.] The species extends to Qld.

\section{Scaevola L.}

S. hookeri (de Vriese) F. Muell. ex Hook. f.

Subalpine, on hillslopes, rarely alpine. [Also in Tas. and Vic., and reaching the N. Tlds of N.S.W.]

\section{STYLIDIACEAE}

Stylidium Sw. ex Willd.

S. graminifolium Sw. ex Willd. Widespread in moist places. [Common in temperate eastern Australia.]

\section{ASTERACEAE}

1. Florets not all ligulate.

2. Outer florets ligulate.

3. Pappus absent or minute.

4. Heads in a dense, broad corymb Achillea 16.

4.* Heads not as above.

5. Achenes contracted into an apical beak Lagenifera 1.

5.* Achenes obtuse Brachycome 2.

3.* Pappus conspicuous; of soft capillary hairs.

6. Ligulate florets white, pink, mauve or blue.

7. Herbs.

8. Ligulate florets in 2 to several rows Erigeron 3.

8.* Ligulate florets in a single row Celmisia 4.

7.* Shrubs Olearia 5.

6.* Ligulate florets yellow. 
9. Involucral bracts membranous and yellowish Podolepis 15.

9.* Involucral bracts herbaceous and green Senecio 19.

2.* Outer florets not ligulate.

10. Apparent head compound, long-pedunculate and usually hemispherical to globoid Craspedia 14

10.* Head simple.

11. Pappus absent.

12. Outer achenes strongly compressed. Leaves scattered Cotula 17.

12.* Outer achenes with rounded angles. Leaves chiefly radical Abrotanella 18.

11.* Pappus present.

13. Pappus composed of scales Rutidosis 13.

13.* Pappus of bristles.

14. Involucral bracts spinescent.

15. Plant pubescent but not white-woolly Cirsium 20.

15.* Plant white-woolly. Onopordum 21.

14.* Involucral bracts not spinescent.

16. Involucral bracts in a single row, herbaceous Senecio 19.

$16{ }^{*}$ Involucral bracts in several series, often with scarious margins.

17. Heads unisexual; sessile or almost so.

18. Leaves pubescent. Involucral bracts with spreading white tips Ewartia 8

18. ${ }^{*}$ Leaves glabrous. Bracts not as above.........Parantennaria 6. 17.* Heads not as above.

19. Achenes beaked. Heads long-pedunculate

Leptorhynchos 12.

19.* Achenes not beaked. Heads various.

20. Heads with outer filiform female florets more numerous than the inner bisexual ones......Gnaphalium 7.

20.* Heads not as above.

21. Florets subtended by an involucre-like bract.

Cassinia 9.

21.* Florets without a subtending bract.

22. Pappus-bristles plumose from the base Helipterum 10.

22.* Pappus-bristles simple, barbellate and slightly plumose towards the apex 
1.* Florets all ligulate.

23. Pappus consisting of scales Microseris 22.

23.* Pappus consisting of bristles.

24. Pappus-bristles plumose with lateral barbs.

25. Fruiting heads $>5 \mathrm{~cm}$ diameter Tragopogon 25.

$25{ }^{*}$ Fruiting heads $3 \mathrm{~cm}$ or less in diameter.

26. Bracts usually glabrous. Scapes usually naked; if with some leaves then the flowers white Hypochoeris 23.

26.* Bracts pubescent. Scapes leafy Picris 24.

24.* Pappus-bristles simple or slightly barbellate.

27. Achenes with very long beaks.

28. Heads few; clustered on panicle-branches Chondrilla 26.

28.* Heads single on a simple scape Taraxacum 27.

$27{ }^{*}$ Achenes beakless or with short beaks.

29. Achenes compressed. Sonchus 28.

29.* Achenes terete Crepis 29.

\section{Lagenifera Cass.}

L. stipitata (Labill.) Druce var. stipitata

At all altitudes. [Widespread especially in cooler parts of southeastern Australia; also in N. Guinea.] Another variety is found in Tas.

\section{Brachycome Cass.}

1. Plant herbaceous or if somewhat shrub-like the anther bearing a terminal appendage.

2. Fruit with a broad wing.

3. Body of the fruit with 2-3 longitudinal folds inside the wing

$B$. radicans Steetz ex Lehm.

In swamps; reaching subalpine levels only in the Happy Jacks area. [Also in Tas. and Vic. and extending to the N. Tlds of N.S.W.]

3.* Body of the fruit not as above.

4. Flowers usually light-purple. Bracts long-tapering at the apex. Leaves broad-spathulate or obovate, crenate or serrate.

B. scapiformis DC. sens. lat.

Widespread and common. Usually in grassland. [Also in Tas. and Vic. and extending to the N. Tlds of N.S.W.] There are two forms (at least) of this variable species in the area. One is a slender plant found on the feldmark. It is usually branched, its leaves taper to a very narrow base and the stalk below the flowerhead is usually $<1 \mathrm{~mm}$ broad. The more common form in the Kosciusko area is variable in size but always much more robust, less branched, with leaves tapering to a broader base and with a robust stalk, usually $>$ $1 \mathrm{~mm}$ (often $2 \mathrm{~mm}$ or more) broad, below the flowerhead. Both these forms and forms with other combinations of these characters are widespread outside the Kosciusko region. 
4. Flowers white. Bracts usually rather obtuse and erose but if tapering then the leaves linear or pinnatisect.

5. Leaves cauline B. aculeata (Labill.) Less.

Widespread at subalpine levels especially in woodland. [Widely distributed in eastern Australia.]

5.* Leaves radical.

6. Leaves once- or twice-pinnatisect B. nivalis F. Muell.

Widespread and common, especially in steep, rocky, shaded places. [Also in Vic. and in other cold parts of the S. Tids of N.S.W.]

6.* Leaves entire or with a few lobes....... B. tadgellii Tovey \& Morris. Widespread in wet places; usually alpine but descending to subalpine parts of the Spencers Creek and Snowy R. valleys. [Also in Tas. and Vic. but not found elsewhere in N.S.W.] This species has previously been included in $B$. nivalis as var. alpina (F. Muell. ex Benth.) G.L. Davis.

2.* Fruit not or scarcely winged.

7. Plants stoloniferous.

8. Plants glandular-pubescent. Leaves lobed

B. tenuiscapa Hook. f. var. tenuiscapa

Rare. Colonizing bare patches. [Also in Tas. and Vic.] The species extends to southern Qld.

8. Plants glabrous. Leaves entire B. stolonifera G.L. Davis Alpine. In moist places. [Endemic.]

7.* Plants not stoloniferous.

9. Fruit with long, straight hairs. Leaves usually $>1.5 \mathrm{~cm}$ wide...... B. decipiens Hook. f. In more sheltered subalpine areas, usually in grassland. [Also in Tas. and Vic. and reaching the C. Tlds of N.S.W.]

9.* Fruit glabrous. Leaves usually $<1.5 \mathrm{~cm}$ wide.

10. Fruit flat. Involucral bracts \pm 12 , obtuse. Leaves usually $>5 \mathrm{~mm}$ wide B. scapigera (Sieber ex Spreng.) DC.

Widespread and common at all altitudes. [Widespread throughout the N.S.W. tablelands, in Vic. and extending to southern Qld.]

10. Fruit turgid. Involucral bracts \pm 20 , rather acute. Leaves usually $<5 \mathrm{~mm}$ wide B. obovata G.L. Davis

At all altitudes in mud or wet places. [Also in Vic. and perhaps elsewhere in southern N.S.W.]

1.* Plant shrub-like and pinnate-leaved. Anther not bearing a terminal appendage B. rigidula (DC.) G.L. Davis

Subalpine, only in the northern part of the area. Not common. [Widespread in eastern Australia.] 


\section{Erigeron L.}

1. Plant tall and almost glabrous E. conyzoides F. Muell. In subalpine areas, often on roadsides. [Also in Vic. (Dargo High Plains) and elsewhere on the S. Tlds of N.S.W.]

1.* Plant low-growing and pubescent.

2. Leaves $\pm 1 \mathrm{~cm}$ long, setose E. setosus (Benth.) M. Gray Alpine, in moist places, especially below snow patches. [Endemic.]

2.* Leaves $>2 \mathrm{~cm}$ long, not setose E. pappocromus Labill.

Widespread and common especially at high altitudes. [Also in Tas., Vic. and on higher peaks of the A.C.T., but elsewhere in N.S.W. only on Gloucester Tops, on the N. Tlds.] Several forms can be distinguished in this group which needs further collection and study. There are three forms in the Kosciusko area. One is almost glabrous and very viscid; in dried specimens, acicular crystals can usually be found on the leaves. The other forms are both pubescent but one is much more delicate, with smaller heads and more attenuate leaf-bases.

\section{Celmisia Cass.}

1. Fruits pubescent.

C. asteliifolia Hook. f. sens. lat.

Common and widespread. [Also in Tas. and Vic., and extending to the C. Tlds of N.S.W.] Several forms can be distinguished in the material from this area.

1.* Fruits glabrous C. longifolia Cass.

Rare. In swampy places. [Extending to the C. Tlds of N.S.W.]

\section{Olearia Moench}

1. Leaves \pm glabrous, smooth and shining, $\pm 2-3 \mathrm{~mm}$ long O. algida N.A. Wakefield

Common in subalpine areas and extending slightly above the treeline. [Also in Tas. and Vic., and elsewhere in colder parts of the S. TIds of N.S.W.]

1.* Leaves pubescent, usually $>5 \mathrm{~mm}$ long.

2. Leaves with hairs of the lower surface appressed and shining

O. erubescens (Sieber ex DC.) Dippel

In sheltered subalpine areas. [Also in Tas. and Vic., and reaching the C. Coast and Tlds of N.S.W.]

2.* Leaves with the lower surface tomentose.

3. Leaves opposite ............ O. megalophylla (F. Muell.) F. Muell. ex Benth. Only in more sheltered subalpine areas. [Also in Vic. and reaching the N. Tlds of N.S.W.]

3.* Leaves alternate.

4. Flower-heads projecting well beyond the leaves. Leaves usually $>1 \mathrm{~cm}$ long and pubescent at least on the lower surface.

5. Leaves with the upper surface glabrous, or almost so, and the margins conspicuously dentate ..... O. phlogopappa (Labill.) DC. var. Subalpine, on hill slopes. [Perhaps elsewhere on the S. Tlds of N.S.W.] 
5.* Leaves with the upper surface stellate-pubescent; the margins not conspicuously dentate.

O. phlogopappa (Labill.) DC. var. flavescens (Hutchinson) J.H. Willis

Widespread on hill slopes. [Also in Vic. and elsewhere on the

S. Tlds of N.S.W.]

4.* Flower-heads scarcely projecting beyond the small $(<1 \mathrm{~cm})$, densely pubescent leaves

O. phlogopappa (Labill.) DC. var. subrepanda (DC.) J.H. Willis

Widespread on hill slopes. [Also in Vic. and elsewhere on the

S. Tlds of N.S.W.]

\section{Parantennaria Beauverd}

P. uniceps (F. Muell.) Beauverd

Alpine and in high subalpine areas, in wet places. [Also in Vic., but found elsewhere in N.S.W. only at high elevations in the A.C.T.]

\section{Gnaphalium L.}

1. Leaf-hairs dense, stout and shining, giving the leaf a satin appearance. Heads solitary G. nitidulum Hook. f.

Alpine and in cooler subalpine areas, in grassland. [Also in Tas., Vic. and N.Z. Not elsewhere in N.S.W.]

1.* Leaf-hairs and heads not as above.

2. Leaves discolorous, the upper surface glabrous or with a more sparse pubescence than the densely pubescent lower surface.

3. Flowers in a dense head surrounded by an involucre of long floral leaves.... $G$. involucratum Forst. f.

Widespread in subalpine areas. [Common in cooler parts of southeastern Australia and in N.Z. and N. Guinea.]

3.* Flowers not as above.

4. Inner involucral bracts laciniate G. umbricola Willis

Widespread. Usually in rock crevices. [Also in Tas. and Vic. and reaching at least the C. Tlds of N.S.W.]

4.* Inner involucral bracts entire G. gymnocephalum DC. sens. lat.

Recorded only from Happy Jacks Plain. In grassland, often in poorly drained depressions. [Widespread in Australia; scattered (especially on the tablelands) in N.S.W.]

$2 .^{*}$ Leaves concolorous, the upper and lower surfaces almost equally pubescent.

5. Flowers in a dense head surrounded by an involucre of long floral leaves. $G$. involucratum Forst. f.

Widespread in subalpine areas. [Common in cooler parts of southeastern Australia and in N.Z. and N. Guinea.]

5.* Flowers not as above. 
6. Heads solitary at the ends of branches. Leaves densely white-woolly. Outer involucral bracts with rather sparse long tangled hairs G. traversii Hook. f.

Subalpine. In damp peaty places. [Also in Tas., Vic. and N.Z. but not elsewhere in N.S.W.]

6. Heads at least several on the flowering stems, or if solitary then the outer involucral bracts either glabrous or with dense hairs.

7. Young flowering heads narrow, usually more than twice as long as broad.

8. Flowering heads usually $6 \mathrm{~mm}$ long. Leaves with a webby tomentum G. sp.

Subalpine, rarely in sheltered alpine places. In grassland and often in bare wet places. [Found elsewhere only in Vic.]

8.* Flowering heads usually $>6 \mathrm{~mm}$ long. Leaves with a close satin tomentum G. fordianum M. Gray Widespread in grassland and often in wet places. [Also in Tas. and Vic. but not found elsewhere in N.S.W.]

7.* Young flowering heads broad, usually less than twice as long as broad. Leaves with a rather woolly tomentum

G. argentifolium N.A. Wakefield

In alpine and cooler subalpine areas, in grassland or among rocks. [Also in Tas. and Vic.]

\section{Ewartia Beauverd}

E. nubigena (F. Muell.) Beauverd

Common and widespread in alpine and exposed subalpine areas, of ten spreading over bare gravel. [Also in Vic.]

\section{Cassinia $\mathrm{R}$. Br.}

C. uncata A. Cunn. ex DC. sens. lat.

Widespread in subalpine areas. Less common in alpine areas. [Also in Vic. and S.A., and extending to southern Qld.] This is a variable species. The material in the Kosciusko district seems to represent a form distinct from the Type (a specimen from northern N.S.W.).

\section{Helipterum DC.}

1. Leaves clothed with a webby or woolly tomentum

H. albicans (A. Cunn.) DC. ssp. alpinum (F. Muell.) P.G. Wilson

Common in exposed parts of alpine areas but also subalpine. [Also in Vic. and on higher parts of the A.C.T.] The species is widespread in southeastern Australia.

1. Leaves subglabrous, the surface glandular-punctate

$H$. anthemoides (Sieber ex Spreng.) DC.

Widespread on hill slopes in subalpine areas, rarely alpine. [Widespread in eastern Australia.] 


\section{Helichrysum Miller}

1. Heads $2-6 \mathrm{~cm}$ diameter, solitary or few.

2. Bracts white, often with purplish markings

$H$. adenophorum F. Muell. var. waddelliae J.H. Willis

Recorded only from Round Mountain and Happy Jacks Plain. [Also in Vic., and extending to the N. Coast in N.S.W.] The species is widespread in Vic. and extends to S.A.

2.* Bracts yellow or golden.

3. Heads yellow $\pm 2-3 \mathrm{~cm}$ diameter. Bracts soft ......... H. scorpioides Labill. Common and widespread, often on grassy slopes. [Widely distributed in southeastern Australia.]

3.* Heads golden-yellow to orange, $\pm 4-6 \mathrm{~cm}$ diameter. Bracts indurated H. acuminatum DC.

Common and widespread, especially on dry hillsides, in subalpine areas. [Also in Tas., Vic. and in other cold parts of the S. Tids of N.S.W.]

1.* Heads $<1 \mathrm{~cm}$ diameter; densely clustered.

4. Leaves closely appressed, $\pm 1-2 \mathrm{~mm}$ long. H. hookeri (Sond.) Druce Common and widespread especially in open and moist subalpine grassland. [Also in Tas., Vic. and elsewhere on the S. Tlds of N.S.W.]

4.* Leaves spreading, 5-30 $\mathrm{mm}$ long.

5. Leaves $15-30 \mathrm{~mm}$ long

H. thyrsoideum (DC.) J.H. Willis \& P.F. Morris

Common in more sheltered subalpine areas. [Also in Tas., Vic. and higher parts of the A.C.T., but not found elsewhere in N.S.W.]

5.* Leaves 5-10 mm long.

6. Mature heads about as wide as long. Leaves pale below and pungent-scented H. secundiflorum N.A. Wakefield

Widespread and common especially on hill slopes in woodland. [Also in Vic. and elsewhere on the S. Tlds of N.S.W.]

6. Mature heads longer than wide. Leaves golden-yellow below and not pungent-scented H. alpinum N.A. Wakefield Common at all altitudes; often on creek flats in subalpine areas. [Also in Vic. and on higher parts of the A.C.T., but not elsewhere in N.S.W.]

\section{Leptorhynchos Less.}

L. squamatus (Labill.) Less. ssp.

Widespread, especially in moist grassland and on rocky places. [This high altitude subspecies is also found elsewhere on the S. Tlds of N.S.W.] The species reaches Tas. Within this subspecies the material is very variable, especially in the amount of pubescence on the upper leaf-surface. This variation is often conspicuous within one population where plants of different coloration intermingle. Densely pubescent plants can be found at all altitudes. 


\section{Rutidosis DC.}
R. leiolepis F. Muell.
Recorded only from Happy Jacks Plain. [Limited to a small part of the S. Tids of N.S.W.]

\section{Craspedia Forst. f.}

For undescribed species I have followed the lettering system adopted by M. Gray in Costin et al. (1979), and extended it to cover the additional species.

1. Flowers white.

2. Leaves broad, green and glabrous C. leucantha F. Muell.

Alpine and high subalpine. On stream banks and in seepage. This species seems to be spreading rapidly. [Endemic.]

2.* Leaves narrow, densely webby C. sp. A

At high alpine altitudes in wet peaty places. [Endemic.]

1.* Flowers yellow or orange.

3. Leaves densely webby over most of their surface.

4. Leaves not long-attenuate at the base. Heads $>2 \mathrm{~cm}$ diameter...C. sp. C Usually alpine, occasionally subalpine. In grassland. [Endemic.]

4. ${ }^{*}$ Leaves long-attenuate at the base. Heads usually $<2 \mathrm{~cm}$ diameter

In lower subalpine areas, especially in grassland. [Also in Tas. and C. sp. G Vic., and elsewhere on the S. Tlds of N.S.W.]

3. ${ }^{*}$ Leaves not densely webby over most of their surface.

5. Leaves green on the upper surface and densely webby below.

6. Leaves with a tapering but not extremely elongated base. Heads usually $>2 \mathrm{~cm}$ diameter. C. sp. B Vic.]

In alpine and colder subalpine areas in rocky places. [Also in

6.* Leaves narrow and extremely elongated at the base. Heads usually $<2 \mathrm{~cm}$ diameter C. $\mathrm{sp} . \mathrm{G}$

In lower subalpine areas especially in grassland. [Also in Tas. and Vic. and elsewhere on the S. Tlds of N.S.W.]

5.* Leaves not as above. Dense webbiness restricted, tending to be confined to the margins.

7. Flowers yellow.

8. Leaves robust. Heads spherical.

9. Rosette spreading and pale-green. Leaf-surface usually loosely pubescent. Leaf-bases not long-attenuate.... C. sp. D

In exposed alpine or high subalpine places, often in drier grassland. [Probably endemic.]

9.* Rosette erect and green. Leaf-surface sparsely hairy or glabrescent. Leaf-bases long-attenuate. C. sp. $\mathrm{E}$ In exposed alpine places, on moist flats or in seepage on hillsides. [Probably endemic.] 
8.* Leaves flaccid. Heads flat-topped C. sp. $\mathrm{H}$

Widespread in lower subalpine areas in grassland. [Also in Vic. and in other high parts of the S. Tlds of N.S.W.] Occasional orange-flowered plants probably indicate hybridization with $C$. sp. I.

7.* Flowers orange.

10. Leaves often long-attenuate at the base with the base of the plant purple. Heads usually $1-1.5 \mathrm{~cm}$ in diameter...

In moist grassland at low subalpine levels. [Endemic.] This species hybridizes with $C$. sp. H.

10. Leaves not long-attenuate at the base or if so then the base of the plant not purple. Heads usually c. $2 \mathrm{~cm}$ or more in diameter.... C. sp. F

In grassland. Common at higher subalpine levels, occasionally in sheltered alpine places where it appears to hybridize with yellow-flowered species. [Probably in Vic., and perhaps reaching the A.C.T.]

\section{Podolepis Labill.}

1. Flower-heads single and terminal............................... jaceoides (Sims) Voss

Recorded only from Happy Jacks Plain. [Widespread in eastern Australia.]

1.* Flower-heads in terminal clusters.

2. Robust plants, the stems densely webby-tomentose

P. robusta (Maiden \& Betche) J.H. Willis

Widespread, especially in subalpine areas. [Also in Vic. and on other high parts of the S. Tlds of N.S.W.]

2.* Slender plants, the stems no more than sparsely webby P. hieracioides F. Muell.

Scarcely, perhaps not, ascending to subalpine levels. [Common in tableland areas of N.S.W. and in Vic.]

\section{6. * Achillea L.}

Planted and naturalized on roadsides in subalpine areas. [Native to the N. Hemisphere and naturalized in cooler parts of Australia.]

\section{Cotula L.}

1. Plants almost glabrous. Leaves singly pinnatifid

C. alpina (Hook. f.) Hook. f.

Common in subalpine areas especially on moist creek-flats, occasionally alpine. [In Tas. and Vic., and, on the S. Tlds of N.S.W., extending to the A.C.T.]

1.* Plants villous. Leaves doubly pinnatifid

C. filicula (Hook. f.) Hook. f. ex Benth.

Common in subalpine areas, on moist flats; rare in sheltered alpine areas. [Also in Tas. and Vic., and reaching the N. Tlds of N.S.W.] 
18. Abrotanella Cass.

A. nivigena (F. Muell.) F. Muell.

Alpine and along the Snowy R. to below Guthega Dam, at $1550 \mathrm{~m}$ altitude. In wet places. Not common. [Also in Vic. but not elsewhere in N.S.W.]

\section{Senecio L.}

1. Outer florets ligulate.

2. Ligulate florets $>4 \mathrm{~mm}$ long S. pectinatus DC.

Alpine and along the Snowy R. to below Guthega Dam, $1550 \mathrm{~m}$ alt.; occasionally in other moist subalpine areas. [Also in Tas. and Vic.]

2.* Ligulate florets to $4 \mathrm{~mm}$ long.

3. Ligulate florets c. 5. Leaves bluntly and irregularly dentate

S. linearifolius A. Rich.

Subalpine, often on the margin of woodland. [Also in Tas. and

Vic. and widespread in N.S.W., reaching the N. Tlds and W. Plains.]

3.* Ligulate florets 11-13. Leaves pinnatifid

S. lautus Forst. f. ex Willd. ssp. alpinus Ali

Common and widespread especially in open places. [Also in Tas. and Vic., elsewhere on the S. Tlds of N.S.W. and extending to the A.C.T.] The species is widespread throughout Australia and in N.Z.

1.* All florets tubular.

4. Leaves broadly oblanceolate to elliptical, usually $>1 \mathrm{~cm}$ wide S. gunnii (Hook. f.) Belcher

Widespread in subalpine areas, occasionally alpine. [Also in Tas. and Vic. and extending to the N. Tlds of N.S.W.]

4. ${ }^{*}$ Leaves oblanceolate, often $<1 \mathrm{~cm}$ wide.

5. Inflorescence lax. Leaves rather acute......S. sp. (aff. apargiifolius Walp.) Scattered in subalpine and sheltered alpine areas. [Widespread throughout Australia.]

5.* Inflorescence usually dense. Leaves rather obtuse $S$. sp. (aff. glomeratus Desf. ex Poir.)

In more sheltered subalpine areas. [Also in Tas. and Vic., and elsewhere on the S. Tlds of N.S.W.]

\section{0. * Cirsium Miller}

1. Plant biennial. Upper leaf-surface prickly ${ }^{*}$ C. vulgare (Savi) Ten.

Occasional at lower subalpine levels. [A widely naturalized native of Europe.]

1.* Plant perennial. Upper leaf-surface not prickly ${ }^{*}$ C. arvense (L.) Scop. Found only on a rubbish-tip near Diggers Creek Lake. [A native of Europe and Asia, widely naturalized but not common in Australia.]

\section{1. * Onopordum L.}

*O. acanthium $\mathrm{L}$.

On a roadside. [A native of Europe widely naturalized in cooler parts of Australia.] 


\section{Microseris D. Don}

M. lanceolata (Walp.) Sch.-Bip. sens. lat. Widespread at all altitudes on moist hillsides. [Throughout temperate Australia.]

23. *Hypochoeris $\mathrm{L}$.

* $H$. radicata $\mathrm{L}$.

Widespread especially in disturbed areas. [Native to the N. Hemisphere. Widely naturalized.]

\section{4. *Picris L.}

*P. hieracioides L. ssp. hieracioides

Common in disturbed areas. [A native of the $\mathrm{N}$. Hemisphere, naturalized in eastern Australia.] Although Lack, Phytologia 42 (1979), considers $P$. hieracioides not to be present in Australia, Kosciusko specimens closely resemble European material.

\section{5. *Tragopogon $\mathrm{L}$.}

*T. dubius Scop.

Along roadsides at lower subalpine levels. [Native to Europe. Naturalized in parts of the S. Tlds of N.S.W.]

\section{6. ${ }^{*}$ Chondrilla $\mathrm{L}$.}

${ }^{*}$ C. juncea $\mathrm{L}$.

In sheltered subalpine areas. [A native of Europe and Asia. Widely naturalized.]

\section{7. *Taraxacum Weber ex Wiggers}

${ }^{*} T$. officinale Weber ex Wiggers sens. lat. Asia.]

Scattered at all altitudes. [A widely naturalized native of Europe and

\section{8. *Sonchus L.}

*S. asper (L.) Hill

Occasional, on roadsides. [A widely naturalized native of Europe.]

\section{9. ${ }^{*}$ Crepis L.}

${ }^{*}$ C. capillaris $(\mathrm{L}$.$) Wallr.$

In disturbed areas at all altitudes. [A native of Europe, naturalized in cooler parts of Australia.] 
INDEX TO FAMILIES

\begin{tabular}{|c|c|}
\hline page & I oganiaceae \\
\hline Apiaceae .... & Loganiaceae............... \\
\hline Araliaceae......... & Lycopodiaceae .......... \\
\hline 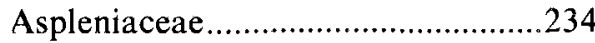 & Malvaceae .......... \\
\hline 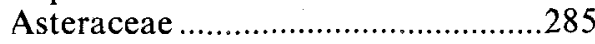 & Mimosaceae... \\
\hline 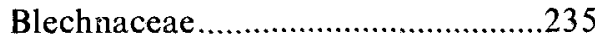 & Myrtaceae............ \\
\hline 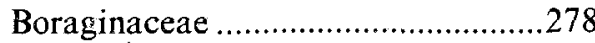 & Onagraceae.......... \\
\hline 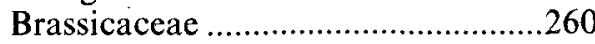 & 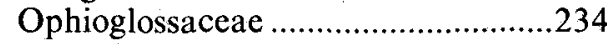 \\
\hline Campanulaceae ............................. & 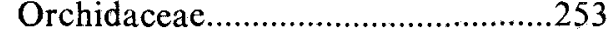 \\
\hline Caryophyllaceae $\ldots \ldots \ldots \ldots \ldots \ldots \ldots \ldots . . . . . . . .$. & 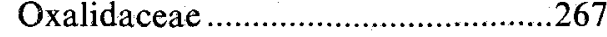 \\
\hline 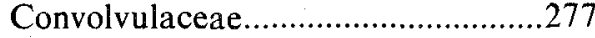 & 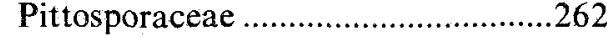 \\
\hline 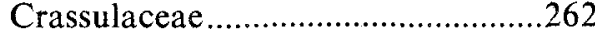 & Plantaginaceae...$\ldots \ldots \ldots \ldots \ldots \ldots \ldots \ldots$ \\
\hline 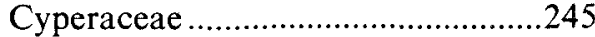 & Poaceae ................ \\
\hline 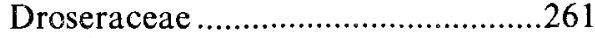 & Podocarpaceae ................................ \\
\hline Elatinaceae .................................... & Polygalaceae \\
\hline 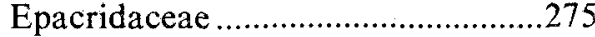 & 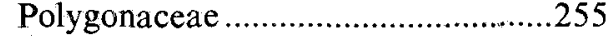 \\
\hline Euphorbiaceae ............................... & 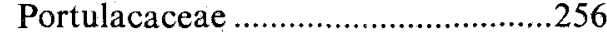 \\
\hline 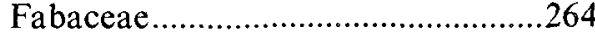 & Potamogetonaceae $. . . . . . . . . . . \ldots \ldots \ldots \ldots . . . . .$. \\
\hline Gentianaceae ................................. & Proteaceae \\
\hline 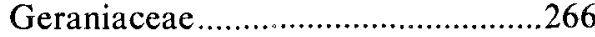 & Ranunculaceae.. \\
\hline Goodeniaceae .............................. & Resedaceae ........ \\
\hline Grammitidaceae...$\ldots \ldots \ldots \ldots \ldots \ldots \ldots \ldots$ & Restionaceae... \\
\hline Haloragaceae ....................... & Rosaceae........ \\
\hline Hymenophyllaceae ..................... & 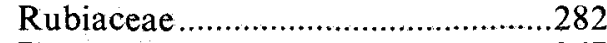 \\
\hline Hypericaceae .............................. & 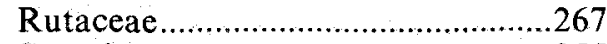 \\
\hline 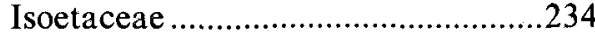 & Santalaceae \\
\hline Juncaceae & Scrophulariaceae \\
\hline Lamiaceae .................................... & Stackhousiaceae ............................268 \\
\hline Lentibulariaceae........................... & 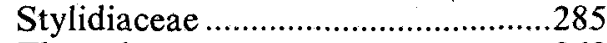 \\
\hline Liliaceae & 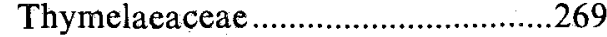 \\
\hline Linaceae & 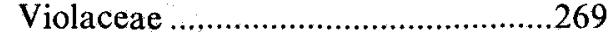 \\
\hline 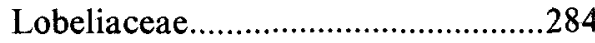 & 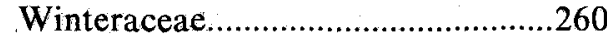 \\
\hline
\end{tabular}

Manuscript received 28.4.1980 